\title{
Review \\ A Literature Review of Energy Efficiency and Sustainability in Manufacturing Systems
}

\author{
Paolo Renna *(D) and Sergio Materi \\ School of Engineering, University of Basilicata, 85100 Potenza, Italy; sergio.materi@unibas.it \\ * Correspondence: paolo.renna@unibas.it
}

Citation: Renna, P.; Materi, S. A

Literature Review of Energy Efficiency and Sustainability in Manufacturing Systems. Appl. Sci. 2021, 11, 7366. https://doi.org/ 10.3390/app11167366

Academic Editor: Anming Hu

Received: 5 July 2021

Accepted: 6 August 2021

Published: 10 August 2021

Publisher's Note: MDPI stays neutral with regard to jurisdictional claims in published maps and institutional affiliations.

Copyright: (c) 2021 by the authors. Licensee MDPI, Basel, Switzerland. This article is an open access article distributed under the terms and conditions of the Creative Commons Attribution (CC BY) license (https:// creativecommons.org/licenses/by/ $4.0 /)$.

\begin{abstract}
Climate change mitigation, the goal of reducing $\mathrm{CO}_{2}$ emissions, more stringent regulations and the increment in energy costs have pushed researchers to study energy efficiency and renewable energy sources. Manufacturing systems are large energy consumers and are thus responsible for huge greenhouse gas emissions; for these reasons, many studies have focused on this topic recently. This review aims to summarize the most important papers on energy efficiency and renewable energy sources in manufacturing systems published in the last fifteen years. The works are grouped together, considering the system typology, i.e., manufacturing system subclasses (single machine, flow shop, job shop, etc.) or the assembly line, the developed energy-saving policies and the implementation of the renewable energy sources in the studied contexts. A description of the main approaches used in the analyzed papers was discussed. The conclusion reports the main findings of the review and suggests future directions for the researchers in the integration of renewable energy in the manufacturing systems consumption models.
\end{abstract}

Keywords: energy efficiency; manufacturing systems; energy saving; renewable energy; sustainable production systems

\section{Introduction and Review Methodology}

In the last five years, as reported in [1], energy-related $\mathrm{CO}_{2}$ emissions have risen $1.3 \%$ per year. It is important that all economic sectors meet zero $\mathrm{CO}_{2}$ emissions at the beginning of the second half of this century in order to limit the increase of the global average temperature to $1.5^{\circ} \mathrm{C}$ [2]. Climate change has several effects on environmental, human and economic aspects; it impacts sea level rise, agriculture, human health, ecosystems, drought and flooding, weather conditions, etc. [3].

Europe, following the path of sustainability and climate change mitigation through the "20-20-20" targets, defined the goals for 2030 [4]: reduction of $40 \%$ of greenhouse gas emissions with respect to 1990 values; a minimum $32 \%$ of renewable energy consumption; and an increment of energy saving of at least 32.5\%. As reported in [1], the transition to a decarbonized global energy system will involve huge investments in energy efficiency, renewable energy sources and enabling infrastructure.

About $24 \%$ and $5 \%$ of the global greenhouse gas emissions are related respectively to industrial energy consumption and to industrial processes [5].

Energy efficiency and renewable energy sources may provide more than $80 \%$ of the emission savings required [2].

For these reasons, scholars have recently focused on energy efficiency and renewable energy sources in the manufacturing system. The motivation behind this review is the importance of energy efficiency and the implementation of renewable energy sources in the industry for more sustainable production that complies with increasingly stringent environmental regulations. This work aims to provide a comprehensive review of the main papers regarding the sustainability and energy efficiency in manufacturing. Electricity price without taxes for non-household consumers varied similarly to the inflation trend 
until 2012 and after presented a decrement [6]. However, as discussed, the persistent increment in taxes has led to a growth in electricity total price (evaluated in the second half of 2020) of $29.5 \%$ with respect to inflation-adjusted prices of the first semester of 2008 . Studies that consider energy and electricity costs were analyzed.

The number of articles regarding energy efficiency and sustainability, analyzed in this review from 2007 until June 2021, is reported in the following figure (Figure 1). The number of papers has grown considerably in recent years.

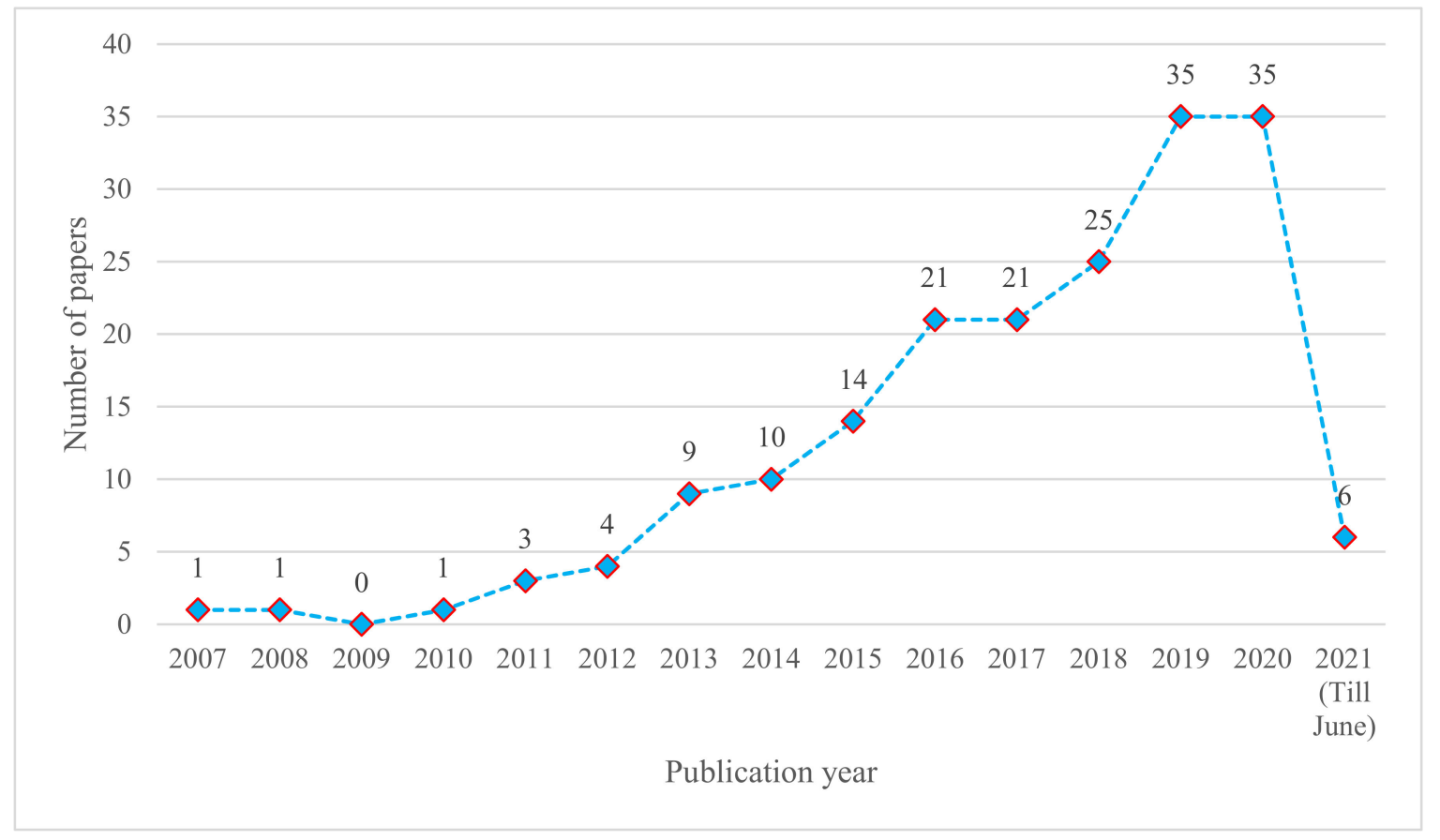

Figure 1. Publication year/number of articles graph.

Figure 2 reports that eight journals in which the greatest number of papers considered in this review are published. The articles are grouped and presented in several years of the International Conference on Automation Science and Engineering (CASE). The other journals or proceedings present less than six articles for each.

This review grouped the papers analyzed into four main groups, which can be split into other classes and subclasses. The four main groups are:

- manufacturing system context;

- assembly line;

- policies and strategies for energy saving;

- renewable energy sources in manufacturing systems.

The first and the second group collected the papers regarding energy efficiency respectively in the manufacturing system and assembly line context. The first is also divided into subclasses considering the type of manufacturing system analyzed.

The policies and strategies for the energy saving group was considered apart from the previous ones as the results achieved concern several typologies of the manufacturing system and can be extended with the appropriate modifications to different contexts or can be starting points for further applications. For the same reason, the studies of renewable energy sources in manufacturing are considered as a separate section. This review considered the different approaches used in the analyzed papers and tried to sort them into different classes considered showing the most used techniques in the literature.

Figure 3 shows the percentage of articles included in each main class and subclasses analyzed. 


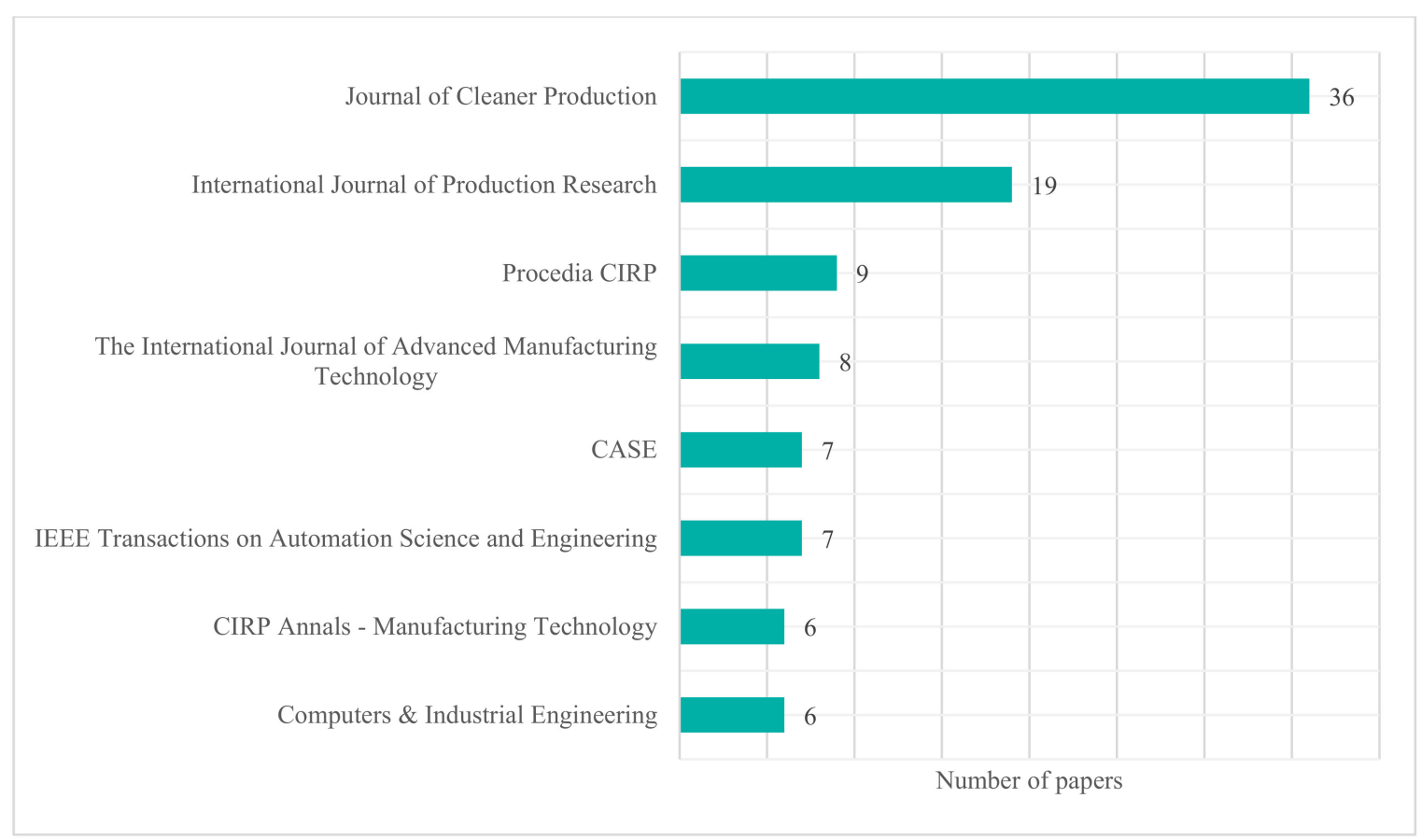

Figure 2. Journal/number of articles graph.

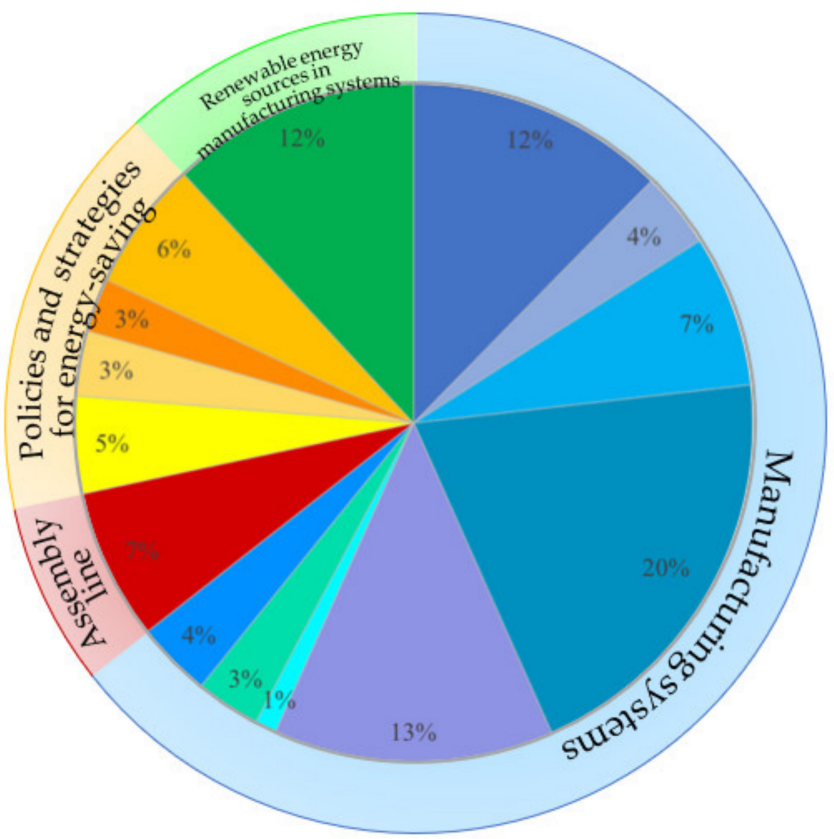

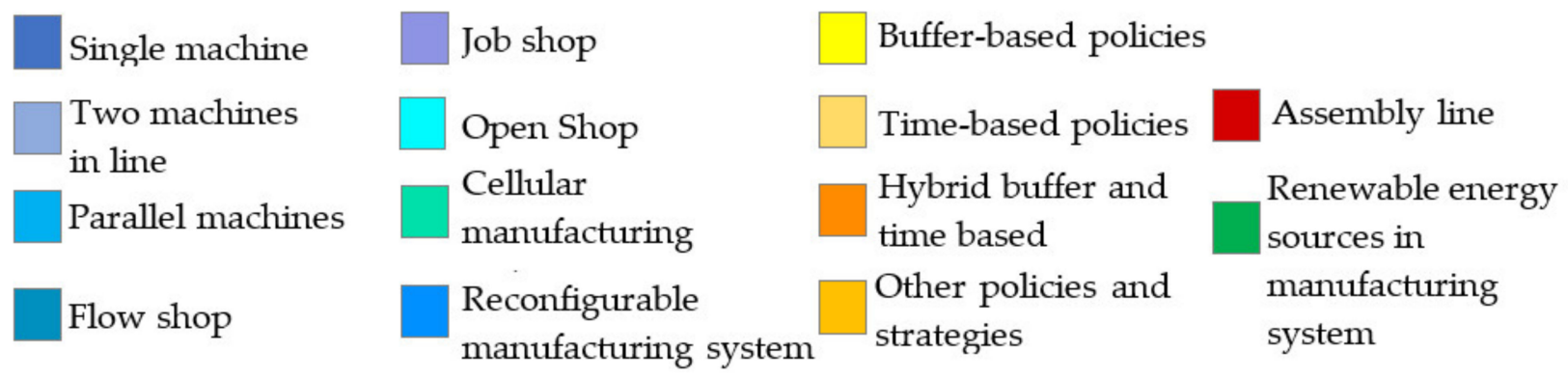

Figure 3. Percentage of papers in each class. 
This review is organized as follows. Sections 2 and 3 present the works regarding energy efficiency respectively in manufacturing systems and in assembly lines. Section 4 focuses on the policies and strategies for energy saving, whereas Section 5 considers the applications of renewable energy sources in manufacturing systems. The approaches and techniques used in the analyzed papers are discussed in Section 6. Finally, Section 7 presents the conclusion of this review and future research directions.

\section{Manufacturing System Context}

In the following section, the main studies focused on energy efficiency and on the reduction of energy consumption in manufacturing systems analyzed.

The section is composed of the following subsections based on the manufacturing level in which the energy-saving actions are applied, or on the characteristic of the manufacturing system:

2.1. Single machine

2.2. Two machines in line

2.3. Parallel machines

2.4. Flow shop

2.5. Job shop

2.6. Open shop

2.7. Cellular manufacturing system

2.8. Reconfigurable manufacturing system

\subsection{Single Machine}

The single machine level is the first grade where energy-saving strategies can be implemented. One of the most approached propositions in the literature for energyefficient machining is the optimization of the process parameters. The papers in the single machine context concerns material removal processes and single-machine scheduling, conventional machining processes, i.e., milling, turning and drilling and the grinding operations (a typical abrasive process), which were selected among several typologies of material removal processes.

In the following, the studies concerning the cutting parameters are grouped according to the type of machining process in Sections 2.1.1-2.1.4. Section 2.1.5 presents the works regarding single machine scheduling with energy aspects.

\subsubsection{Milling}

Calvanese et al. [7] found the optimal cutting condition in terms of cutting speed and feed rate in order to minimize energy consumption of a machine tool. In their work, an analytical model for the energy characterization of a computer numerical control milling center was discussed.

In the same context, Albertelli et al. [8] provided an energy consumption model of a machine tool required during face milling operation. In the evaluation of energy consumption, several components needed for the milling, the cutting energy and the passive phase energy were considered. The objective function is the minimization of energy consumption and the cutting speed, the feed rate and the radial depth of cut, which were considered as parameters of the optimization. Other works concerning energy consumption, defined as one of the multiple objectives of the optimization in milling achievable through the proper selection of the cutting parameters, can be found in $[9,10]$. Approaching energy consumption, J. Yan and Li [11] considered material removal rate, surface roughness and cutting energy as the optimization objectives and addressed the investigation of best parameters (spindle feed, feed rate, depth of cut and width of cut) using the weighted grey relational analysis and response surface methodology. Moreover, a Cuckoo search algorithm was applied to a multi-objective optimization model, considering the minimization of the energy footprint and of production time [12]. Another metaheuristic algorithm was used for energy optimization in the milling context [13]. In their work, W. 
Wang et al. [13] developed a dual-objective optimization model, i.e., the minimization of power consumption and of processing time and used an artificial bee colony algorithm to solve the mathematical problem to find the best parameters. T. Zhang et al. [14] developed a mechanical milling power model with the aim of analyzing the main milling parameter effects on the specific milling energy, specific removing energy and energy efficiency. The main result of the study is that the lower the rotational speed, the feed rate per tooth, the axial cutting depth and the cutting width, the higher the specific removing energy. This outcome is due to the increment of idle energy. The authors argued that an increment of the milling parameters leads to a higher value of energy efficiency.

\subsubsection{Turning}

Hanafi et al. [15] applied a grey relational theory and Taguchi optimization for the minimization of power consumption and of the surface roughness during a turning process. The authors showed that using Pareto analysis, the depth of cut, followed by cutting speed and feed rate, are the parameters that most impacts the optimization objectives. Rajemi et al. [16] proposed a machining energy model with the aim of finding the cutting speed that allows minimizing energy consumption. They argued that the best energy conditions are not always the same for the minimum cost criterion. Another work concerning the energy saving, in turn, can be found in [17]. In the paper, the effect of the cutting depth, feed rate and cutting speed was studied and the optimization model, which considers as objectives the energy, cost and quality, was developed and solved using a non-dominated sorting genetic algorithm II (NSGA-II).

\subsubsection{Drilling}

Mori et al. [18] showed that power consumption reduction can be achieved by the selection of cutting conditions in drilling in addition to face/end milling. Moreover, they argued that an appropriate pecking cycle and the synchronization of the spindle with the feeding system led to a reduction in power consumption.

Analyzing the energy efficiency in drilling, Zhongwei Zhang et al. [19] proposed a mathematical model in order to minimize energy consumption and processing time. In their study, a deep-hole drilling process with two drills was considered and a particle swarm optimization-based algorithm was applied to find the best parameters setting. The energy prediction models in drilling $[20,21]$ are useful tools to obtain energy savings.

\subsubsection{Grinding}

Regarding the grinding process, Heinzel and Kolkwitz [22] analyzed the effect of fluid supply on energy efficiency. The results showed that the modular nozzle has higher energy efficiency than the tangential flat nozzle despite the higher power consumption. The flowrate has an impact on the specific energy; therefore, the higher the flowrate, the higher the energy efficiency.

The eco-efficiency can be achieved by an optimal selection of the main influencing grinding parameters and by considering surface roughness, costs and carbon footprint as the objectives of the optimization process [23]. Other works regarding eco-efficiency and energy consumption in grinding can be found in $[24,25]$.

\subsubsection{Single Machine Scheduling}

In the single machine scheduling context, Mouzon and Yildirim [26] developed a framework in order to minimize total energy consumption and total tardiness. In their work, an approximate Pareto front was obtained using a greedy randomized multi-objective adaptive search metaheuristic method and the solutions were compared using an analytical hierarchy process.

The minimization of the total completion time and of the total energy was selected as the optimization objective in [27] and a genetic algorithm was implemented to address the problem. Appropriate single machine production scheduling was used to reduce the energy 
cost [28]. The authors considered the variable energy cost; the job starting time, the idle and inactive time and the energy cost were obtained using the proposed scheduling model.

Shijin Wang et al. [29] addressed bi-objective single-machine batch scheduling with different job sizes, the time-of-use electricity tariffs and various machine energy consumptions to minimize both the total energy cost and the makespan. Two decomposition-based heuristic methods and an $\varepsilon$-constraint method were applied to find respectively the approximate and the exact Pareto front.

Based on the work of Shijin Wang et al. [29], S. Zhang et al. [30] proposed two improved heuristic methods to solve the problem.

\subsection{Two Machines in Line}

The simplest multi-machine configuration is a manufacturing system composed of two machines in line. This setup is defined as a flow shop with two machines. Regarding the context of the two-machine sequence-dependent permutation flow shop, the compromise between the minimization of energy consumption and of the makespan was studied in [31]. Addressing this aim and finding the Pareto frontier, they proposed a mixed integer linear multi-objective optimization model and developed a constructive heuristic method to solve it. In subsequent work, this study is further analyzed and a new constructive heuristic method was implemented with the purpose of outperforming the previous one [32]. The single job two machines scheduling problem was studied in [33]. In their work, the authors considered the possibility of dividing the job into several sublots with each characterized by different processing speeds. With these considerations, the aim of the paper is to obtain the optimal schedule (the size of the sublots and the processing speeds) that allows for minimizing total energy consumption. Assia et al. [34] analyzed energy-saving through scheduling in a flow shop composed of two machines. In the paper, a mixed integer linear programming with two objectives is proposed; the mathematical model was solved with an exact method in order to minimize the makespan and total energy consumption. The optimization process provides the production and preventive maintenance planning that results in a minimization of the considered targets. Considering that electricity cost can be an alternative way to address energy efficiency, the energy costs are usually higher during the power peak period; thus, avoiding high power consumption when electricity prices are high leads to less electric line saturation. Shijin Wang, Zhu et al. [35] provided a two-machine permutation flow shop scheduling model in order to minimize the total electricity cost, considering the electrical cost during the time variable. The authors used two heuristic algorithms to obtain the optimal schedule and, in addition, proposed an iterated local search method. In another approach discussed in [36], the minimization of the total electricity cost was achieved considering the minimum makespan fixed and under time-of-use electricity tariffs; six heuristic algorithms, three based on Johnson's rule and three based on Hadda's algorithm, were proposed and tested. C.-B. Yan [37] studied energy consumption optimization problems in a two machines serial line considering the Bernoulli reliability model.

\subsection{Parallel Machines}

In this subsection, the papers regarding the energy efficiency in parallel machine context were grouped. A parallel machine system can be distinguished as identical, uniform, and unrelated [38]. Section 2.3.4 reports the works regarding a combination of the previous classes.

\subsubsection{Identical Parallel Machines}

In this case, the parallel machines of the manufacturing system are identical and work at the same speed.

The simultaneous minimization of the makespan and of the total electricity cost in identical parallel batch-processing machines was studied in [39]. The scheduling problem was solved using a Pareto-based ant colony algorithm. 
Together, with electricity cost under time-of-use tariffs, the total weighted tardiness was considered as one of the targets of the optimization process, which is addressed with the $\varepsilon$-constraint method and with three heuristic methods based on grouping genetic algorithms [40]. The $\varepsilon$-constraint method is suitable for the small-scale instances and it was applied for the identical parallel machine scheduling problem considering total energy consumption and the makespan as the objectives of the optimization [41]. Instead, for the medium and large scale instances, a developed constructive heuristic model with local search strategy and a non-dominated sorting genetic algorithm II were used. C.-H. Liu et al. [42] studied the concomitant minimization of the total weighted tardiness for one job and of the total completion time for another one considering a constraint on peak power consumption. The set of solutions was obtained using a domination number-based genetic algorithm.

\subsubsection{Uniform Parallel Machines}

The uniform parallel machines can work at different processing speeds.

A scheduling model solved by a differential evolution algorithm and considering the makespan and the total electricity cost minimization, in the context of uniform parallel batch processing machines, can be found in [43]. Zandi et al. [44] proposed a heuristic algorithm addressing the scheduling problem. The proposed method returns an exact Pareto frontier of total energy consumption and of the total completion time.

\subsubsection{Unrelated Parallel Machines}

Parallel machines are defined unrelated if processing time depends on the machine speed and the speed is specific per each machine and job matching.

The scheduling problem concerning the unrelated parallel machine environment was analyzed by Kurniawan et al. [45]. In their work, a genetic algorithm was developed in order to minimize the total cost composed of the makespan cost and electricity cost, which is considered variable during the periods.

Considering the time of use of electricity tariffs, two different approaches based on a genetic algorithm were used to minimize the total cost composed of the makespan cost and electricity cost $[45,46]$. Saberi-Aliabad et al. [47] developed a mixed integer linear programming model with the objective of the minimization of the consuming energy cost, considering different electricity tariffs. In addition, a fix-and-relax heuristic algorithm was proposed to address a large-sized instances problem.

In the same manufacturing context, a memetic differential algorithm was applied to minimize both the makespan and total energy consumption [48].

To minimize the total tardiness, including also total energy consumption as a non-key objective, an imperialist competitive algorithm was proposed [49]. The simulation results show the feasibility of using the algorithm proposed in the low carbon parallel unrelated machine scheduling context.

Meng, Zhang, Shao, Ren et al. [50] developed a five mixed integer linear programming model for the unrelated parallel machine scheduling of a hybrid flow shop. In this study, the energy saving was obtained by machines turning off and on, reducing, in this manner, energy consumption in the idle state. An improved genetic algorithm for addressing the minimization of total energy consumption was proposed and compared with other optimization algorithms.

Cota et al. [51] provided a mixed integer linear programming model in order to minimize the makespan and total electricity consumption. Using a developed heuristic algorithm, called multi-objective smart pool search metaheuristic, the solution of the problem returns the allocation and the order of the jobs and the processing speed.

\subsubsection{Hybrid Parallel Machines}

In [52] a scheduling problem with the objective of total electricity cost minimization, considering the electrical prices variable during the time, was studied in a two-stage 
parallel machine context. The manufacturing system consists of identical parallel machines and unrelated parallel machines respectively at stage 1 and at stage 2 . A tabu search-greedy insertion hybrid algorithm was developed to solve the new continuous-time mixed-integer linear programming model.

\subsection{Flow Shop}

In the flow shop context, scheduling is still a good strategy for energy saving and efficiency. Flow shop with specific characteristic are grouped in Sections 2.4.1 and 2.4.2.

Hao Zhang et al. [53] provided a time-indexed integer programming with the aim of minimizing electricity cost and $\mathrm{CO}_{2}$ emissions, without reducing productivity. The authors argued that shifting the greatest energy demands during off and mid peak hours leads to a reduction in electricity costs. However, $\mathrm{CO}_{2}$ reduction does not always meet electricity cost reduction; the $\mathrm{CO}_{2}$ emissions per $\mathrm{kWh}$ depend on the mix of power resources used and how they are combined during peak hours.

The peak power consumption was evaluated as an important issue of the flow shop scheduling in [54]. The proposed approach considers the uncertain processing time of the operations and consists of first obtaining the initial schedule that allows minimizing the peak power consumption and the inventory cost. In a second phase, a rescheduling is provided to prevent the peak power due to the uncertainty of processing time, including idle times.

Differing from the other works on the scheduling problem, G.-S. Liu, Yang et al. [55] considered the minimization of energy consumption with the evaluation of the product quality. The machine speed influences the production time, energy consumption, and product quality. Quality control was considered at the end of the line and if the product quality does not satisfy the requirement, it is necessary to rework the piece with additional energy consumption and time. The authors developed a novel three-stage decomposition approach to address the scheduling problem.

In [56] the sum of energy consumption and tardiness was considered as the target of the optimization process. Fuzzy numbers were formulated to consider the uncertainty in the scheduling problem and a genetic algorithm was applied to solve it. In [57], the fuzzy numbers were used to consider the uncertainty of processing time; in this paper, the minimization of the total weighted delivery penalty and of total energy consumption was defined as an objective function, and a multi-objective differential evolution algorithm was provided. The flow line was considered as a Bernoulli serial line with the aim of improving energy efficiency by scheduling machine shutdowns [58].

The problem of a single item capacitated lot-sizing in flow shop, considering energy aspects, was studied in [59]. In this paper, two mixed integer programming models were developed in order to minimize the total production cost consisting of electrical, holding, setup, and power demand costs. Extending this work to address the lot-sizing problem in the case of the medium and large scale, Masmoudi et al. [60] proposed two heuristic methods based on movement techniques and Masmoudi et al. [61] developed a fix-and-relax heuristic and a genetic algorithm. The multi-item capacitated sizing problem, considering energy aspects, was investigated in [62].

The blocking is typical in a flow shop system without buffers between machines or with limited and full intermediate buffers [63]. This blocking condition imposes the impossibility of leaving the upstream machine until the job on the next machine is completed.

In the blocking flow shop context, a scheduling problem considering energy saving was proposed [64]. The authors considered the minimization of the makespan and of energy consumption during job blocks and machine idle time. A discrete multi-objective evolutionary optimization algorithm was used to address the problem.

With the goal of the efficient use of switch-off policies, Renna and Materi [65] developed a mathematical design model of production flow lines 


\subsubsection{Permutation Flow Shop}

The permutation flow shops are characterized by a fixed order of the jobs through the machines [66].

Controlling power peak is an important issue in energy efficiency. A scheduling model that considers peak power as a constraint and makespan as the objective function was discussed in [67]. E. Jiang and Wang [68] considered, as objectives of the scheduling problem, the maximum completion time and total energy consumption and addressed the optimization using an evolutionary algorithm based on decomposition. The flow shop analyzed was characterized by the setup time of each job depending on the sequence.

Lu et al. [69] extended the permutation flow shop scheduling problem, considering in their model, transportation time, sequence-dependent setup time, and energy consumption in the setup stage and in the transportation phase and in the public period with the classical time and energy features. A hybrid multi-objective backtracking search algorithm was provided to solve the scheduling model.

A mixed integer linear programming model was developed in [70], considering as objective function the minimization of the total flow time and of total energy consumption and assuming a machine variable processing speed. To address the problem for small instances, an $\varepsilon$-constraint approach was proposed, whereas for the large instance problems, an $\varepsilon$-constraint approach and two iterated greedy algorithms, a variable block insertion heuristic algorithm, and construction heuristic procedure were provided. Utama et al. [71] developed a hybrid whale optimization algorithm in order to minimize energy consumption in a permutation flow shop scheduling with a dependent sequence setup. Xueqi $\mathrm{Wu}$ and Che [72] considered the simultaneous minimization of the makespan and total energy consumption in the no-wait permutation flow shop scheduling problem. In their study, machine processing speeds were adapted, respecting the objective functions, and an adaptive multi-objective variable neighborhood search algorithm was used to achieve the Pareto front.

In the same manufacturing context, total energy consumption and the total tardiness were considered as objective functions and three metaheuristic algorithms (an ant colony algorithm, a genetic algorithm, and a genetic algorithm with local search) are provided in [73].

The distributed permutation flow shop is a general case of a permutational flow shop characterized by several identical factories, each of them consisting of the same machines arranged in series [74]. J. Chen et al. [75] proposed a scheduling model for the distributed no-idle permutation flow shop context, with the aim of minimizing total energy consumption and the makespan using a collaborative optimization algorithm. The same targets were considered in [76] regarding distributed permutation flow shop. In this work, the problem is solved using a knowledge-based cooperative algorithm.

\subsubsection{Flexible Flow Shop}

The flexible flow shop can be defined as "a generalization of the flow shop and the parallel machine environments" [63].

Regarding the flexible flow shop, Bruzzone et al. [77] proposed an approach based on two phases to consider peak power in the scheduling problem. In the first phase using mixed integer programming, a production schedule is obtained in order to minimize the weighted sum of the total tardiness and the makespan, without considering a power constraint. The machine assignments and job sequences were defined solving the mathematical model and, considering these values fixed and defining a power constraint, the mathematical model is resolved. The new schedule respects the limits on power consumption but can have a worsening of the objective function compared to the previous planning. Dai et al. [78] used a genetic-simulated annealing algorithm to obtain the minimization of the maximum completion time and total energy consumption in a flexible flow shop scheduling problem. An ant colony optimization algorithm was applied in the multiobjec- 
tive hybrid flow shop scheduling [79]; the minimization targets are the makespan and the electrical power cost and time-of-use tariff is considered.

Unlike other works, Gong et al. [80] considered worker flexibility to achieve energy efficiency. The authors developed a mathematical model in which the objective functions to be minimized are the makespan, the total worker cost, and the green production indicator. The last one is composed of energy consumption, the noise, the recycling rate of tool chips, and the safety coefficient. The mathematical model was solved using a hybrid evolutionary algorithm. The minimization of energy consumption costs considering three possible machine states (standby, shut-down, and operation) was studied and solved with a hybrid genetic algorithm in [81]. Hasani and Hosseini [82] considered, in the bi-objective scheduling problem, production cost and energy consumption as the two targets to be minimized and implemented a makespan constraint. The investigated flexible flow shop consists of unrelated parallel machines in the first stage and a single machine in the next stages; a non-dominated sorting genetic algorithm II was used to address the problem. A dynamic scheduling model with the aim of minimizing the weighted aggregation of the makespan and the total tardiness, considering a bound on the power peak, was analyzed in [83]. The dynamic features of scheduling were also studied in [84]. The authors considered the makespan and energy consumption as the objective functions and solved the scheduling problem with an improved particle swarm optimization method. A non-dominated sorting genetic algorithm II and a non-dominated ranked genetic algorithm were used and tested in scheduling problems with two objective functions, i.e., the total weighted tardiness and energy consumption, in [85]. J. Yan et al. [86] proposed an energy-efficient method based on multi-level optimization. The proposed approach aims to combine energy saving at the machine level and at the line level. The cutting energy and the cutting time were considered as objectives in the machine tool level, whereas in the shop floor level the makespan and total energy consumption were defined as the targets; the optimization was achieved using grey relational analysis and a genetic algorithm respectively at the machine and at the line grade. The flexible flow shop scheduling problem, considering the time of use electricity tariffs and makespan and electricity cost as the objective functions, was addressed using an improved strength Pareto evolutionary algorithm in [87]. In addition to two typical objective functions in energy-efficient scheduling, i.e., the makespan and electricity consumption, Zeng et al. [88] considered material wastage as one of the multi-targets of the optimization process. The mathematical model was solved with a hybrid non-dominated sorting genetic algorithm II. New teachers' teaching-learning-based optimization was proposed in the context of the hybrid flow shop scheduling problem [89]. The total tardiness and total energy consumption were considered respectively as the key objective and the non-key objective. T.-L. Chen et al. [90] provided a mixed integer programming with two objective functions, i.e., the minimization of the makespan and electric power consumption. The approximate Pareto solutions were obtained using a non-dominated sorting genetic algorithm II. The simultaneous minimization of the total weighted tardiness and total price of the non-processing energy was investigated and addressed using an evolutionary algorithm based on decomposition in [91]. Jun-qing Li et al. [92] studied the hybrid flow shop scheduling problem, considering, as objectives, the minimization of total energy consumption and of the makespan. The authors developed an algorithm characterized by exploitation search, deep-exploitation phases, exploration, and deep-exploration phases to achieve optimization targets. The minimization of the total tardiness and energy cost considering variable discrete production speeds was analyzed in [93]. S. Schulz et al. [94] considered three objectives, i.e., makespan, total energy cost, and peak load and provided an iterated local search algorithm to address the optimization scheduling problem.

\subsection{Job Shop}

Works regarding the energy efficiency in the classical job shop are discussed in Section 2.5.1. Section 2.5.2 grouped the paper related to the flexible job shop configuration. 


\subsubsection{Classical Job Shop}

Kemmoe et al. [95] designed a mathematical model considering different power requirements in the initial phase and processing phase and selected the makespan as the objective function. The aim of the paper is to define a feasible production schedule that allows respecting the variable power threshold; the authors provided a randomized adaptive search procedure hybridized with an evolutionary local search to solve the problem.

Tang and Dai [96] proposed achieving energy saving by starting from a defined schedule. The first phase consists of obtaining a production planning in order to minimize the makespan. Then, considering the machine assignments and the job sequences fixed, the approach aims to minimize energy consumption by modifying the cutting speeds. The authors provided a genetic-simulated annealing algorithm to solve the problem.

The minimization of the makespan and of total energy consumption, considering different speed rates, was selected as the objective function in [97,98]; the job shop scheduling problem was solved using a genetic algorithm.

Together with the previously optimization targets, Yin et al. [99] assumed that noise is affected by the machining spindle speed and provided a genetic algorithm based on a simplex lattice design to solve the mixed integer programming model.

Masmoudi et al. [100] proposed two integer linear programming models to minimize the energy production costs under power peak constraints and used a heuristic method to solve the mathematical problem.

One of the widely used heuristic models is the genetic algorithm. R. Zhang and Chiong [101] studied the scheduling problem in a job shop system, including the minimization of energy consumption. The developed genetic algorithm optimizes the scheduling problem by integrating the two sub-problems derived from the original model to reduce the computational complexity. A genetic algorithm was implemented in the job shop scheduling model to obtain Pareto front solutions with energy consumption, and makespan as objectives in [102]. Nie et al. [103] modeled the job shop scheduling using game theory and solved the problem using a genetic algorithm. H. Wang et al. [104] proposed an approach that applies modified genetic algorithm (MGA) at the first stage and a hybrid method that integrates a genetic algorithm (GA) with particle swarm optimization (PSO) at the second stage. The model was tested for a flexible job shop scheduling problem.

Lei et al. [105] developed a two-phase meta-heuristic based on the imperialist competitive algorithm and variable neighborhood search in order to achieve a solution for the flexible job shop scheduling problem; the proposed algorithm allows obtaining the minimization of the total tardiness and of the makespan, considering total energy consumption as a constraint.

Renna [106] used a Gale-Shapley algorithm to share power among the machines of a manufacturing system under a peak power constraint. Ebrahimi et al. [107] analyzed the application and the performance of four metaheuristic algorithms in the flexible job shop context. In their work, the minimization of a single objective function obtained as the sum of the energy cost and the tardiness penalty was considered. The algorithms tested were two variants of the particle swarm optimization and two variants of the ant colony optimization. The best results considering both objective function and CPU time were obtained with the hybrid ant colony optimization and simulated annealing algorithm.

Abedi et al. [108] considered the variable speed of the machines and the productivity deterioration; the minimization of the total weighted tardiness and total energy consumption can be achieved by properly selecting the operation sequences and the machine speeds. A multi-population and multi-objective memetic algorithm with periodic local search was provided to address the optimization goal. L. Zhang, Li, Królczyk et al. [109] introduced an effective gene expression programming-based rule mining algorithm to define dispatching rules. In their work, the objective function is the minimization of total energy consumption composed of direct and indirect energy consumption.

The energy-efficient scheduling solved using respectively an improved whale and a grey wolf optimization algorithms can be found in [110] and in [111]. The scheduling 
problem is designed in order to obtain in the first paper the minimization of the sum of energy consumption cost and the completion-time cost and in the second, the minimization of the total cost of energy consumption and tardiness.

In the distributed job shop scheduling context, i.e., an extension of the job shop that considers several factories, a multi-objective evolutionary algorithm with decomposition was used to solve the mathematical model, considering the minimization of the makespan and total energy consumption [112].

\subsubsection{Flexible Job Shop}

The flexible job shop is defined as "a generalization of the job shop and the parallel machine environments" [63].

Regarding the flexible job shop scheduling problem, Moon and Park [113] developed mixed-integer programming and constraint programming approaches with the goal of obtaining the minimization of the total production cost. The total production cost is defined as the sum of the cost linked to the makespan and electricity cost. Furthermore, the model is improved considering the cost related to energy storage and distributed energy resources. Meng, Zhang, Shao and Ren [114] provided several mixed integer linear programming models, selecting, as an objective function, the minimization of total energy consumption. Lei et al. [115] selected the workload balance instead of time-related targets, together with total energy consumption as one of the minimization objectives. The mathematical model was solved using a shuffled frog-leaping algorithm.

The simultaneous minimization of total energy consumption and the makespan in a flexible job shop with variable processing speed context was obtained using a multiobjective grey wolf optimization algorithm [116].

The same targets of the optimization process were considered in [117]. In addition, in the paper, a transportation constraint was implemented due to its high energy impact. The mathematical problem was solved using a genetic algorithm.

Mokhtari and Hasani [118] provided a mathematical model with three objective functions, i.e., the total completion time, the total availability of the system, and the total energy cost and addressed it using an enhanced evolutionary algorithm.

The number of machine turning on/offs was considered as a minimization objective with total energy consumption and the makespan in [119]. The non-dominated sorted genetic algorithm II and a green scheduling heuristic method were implemented to deal with the mathematical model.

In the context of a distributed and flexible job shop, Jin Wang et al. [120] applied edge computing and the industrial internet of things in real-time scheduling. The real-time scheduling method proposed allows for considering real-time data for the operations assignment, and the real-time operations allocation was performed using an evolutionary game-based method.

\subsection{Open Shop}

The literature is lacking in papers regarding the energy efficiency in the open shop systems. The researchers focused mainly, in this context, to the classical optimization objectives such as the minimization of the makespan [121,122], maximum lateness [123], number of late jobs [124], weighted number of late jobs [125] and of total completion time [126,127]. Hosseinabadi et al. [128] considered the open-shop scheduling problem with the objective to minimize the makespan. The genetic algorithm developed can find more optimal solutions for all types of problems and can find them in shorter computational times compared to the other algorithms.

Works regarding the open shop considering energy issues were developed in speedscaling processor studies. Bampis et al. [129] investigated the scheduling problem of an open shop with a speed-scaling setting, considering, as the objective function, the minimization of the makespan with a constrain on the energy budget. The scheduling problem in speed scaling setting was formulated as a convex flow problem in [130]. The 
proposed approach was applied to the preemptive open-shop speed-scaling problem in order to minimize energy consumption.

\subsection{Cellular Manufacturing System}

Referring to the design of cellular facility layout, a mathematical model with minimization of the total cost and the total energy loss, as objective, was proposed and solved using a non-dominated sorting genetic algorithm II in [131]. Niakan et al. [132] extended the studying of sustainable dynamic cellular manufacturing system and included in the second objective function not only energy loss but also other waste such as chemical, raw material waste, and greenhouse gas emission. Imran et al. [133] focused on cell formation with the aim of minimizing the value-added work in process considering electricity cost of the machine and of the material handling system. A simulation integrated hybrid genetic algorithm, i.e., the integration of a genetic algorithm and discrete event simulation, addressed the layout design. Iqbal and Al-Ghamdi [134] investigated the energy saving obtainable by properly assigning the manufacturing process to the machine and selecting the machines in each cell. The problem was solved using a simulated annealing algorithm. Saddikuti and Pesaru [135] aimed to minimize makespan, flowtime, and energy consumption and proposed a non-dominated sorting genetic algorithm II to solve the model.

Lamba et al. [136] developed a mixed integer non-linear model, and a simulated annealing meta-heuristic approach was used to address the optimization problem. The objective function is the minimization of the sum of the material handling cost, the rearrangement cost (both considering inter and intra cell movement) and the total electrical cost.

\subsection{Reconfigurable Manufacturing System}

Choi and Xirouchakis [137] proposed an approach based on holistic production planning to address an energy consumption problem in the reconfigurable manufacturing system. A linear programming model was developed considering part handling systems in energy consumption; the maximization of the throughput and the minimization of energy consumption were selected as objective functions. J. Zhang et al. [138] investigated the energy saving obtainable by a dynamic local reconfiguration, i.e., the switch from the working to energy-efficient mode of the system. Energy was considered in the total cost in [139]. The authors investigated the reconfigurable manufacturing system considering both the design and the manufacturing phase; a mixed integer programming model was proposed with the objectives of the minimization of the total cost and the cycle time. The mathematical model was addressed with an $\varepsilon$-constraint method and with a multi-objective simulated annealing algorithm respectively for small and practical problem sizes. Touzout and Benyoucef [140] studied the process plan generation problem. In this paper, a mathematical model was proposed with the aim of minimizing the total production cost, the completion time, and the greenhouse gas emissions; the latter was evaluated, considering total energy consumption. An iterative multi-objective integer linear programming approach, an archived multi-objective simulated annealing, and the non-dominated sorting genetic algorithm were used and investigated. Regarding a sustainable process plan, three objectives, i.e., the minimizations of the total production cost, of the total production time and of an environmental criterion, were identified and considered in [141-143]. Energy consumption is defined as the environmental objective in [141], whereas Khezri et al. [142,143] considered energy consumption to have impacts on the amount of the greenhouse gas emissions included in the environmental criterion, which is, respectively in the two papers, the sustainability metric value and environmental hazardous wastes. In [142], a posteriori approach, a non-dominated sorting genetic algorithm II, and a strength Pareto evolutionary algorithm II were used to solve the mathematical model, whereas in [143] an adapted version of weighted goal programming was implemented. Khezri et al. [141] addressed the problem using an augmented $\varepsilon$-constraint based approach. 


\section{Assembly Line}

Abdullah et al. [144] developed an assembly sequence planning model in order to achieve energy efficiency. The objective function considered is the weighted sum of the number of tool changes, of the number of assembly direction changes and of energy consumption in idle mode. The problem was solved using a moth flame optimization algorithm.

In robotic and automatic assembly lines, the energy saving is an important issue and several papers in literature focused on this topic. Michalos et al. [145] proposed an approach based on two stages to design and configure the assembly line, considering multiple criteria, one of which is resource energy consumption.

Nilakantan et al. [146] and Nilakantan, Ponnambalam et al. [147] used particle swarm optimization and a differential evolutionary algorithm to minimize energy consumption in a U-shaped robotic assembly line. The particle swarm optimization algorithm was also implemented to address the straight robotic assembly line, considering the simultaneous minimization of total energy consumption and the cycle time [148]. B. Sun et al. [149] aimed to minimize the previously cited objective functions using a bound-guided hybrid estimation of distribution algorithm. In the same robotic assembly line context, i.e., straight line, Nilakantan et al. [150] proposed a multi-objective co-operative co-evolutionary algorithm to address the problem of minimizing the total carbon footprint and maximizing the line efficiency.

Several studies focused on the U-shaped robotic assembly line and different approaches were proposed to address the complexity of the problem. Zikai Zhang, Tang, Li et al. [151] provided a mathematical model for the assembly line balancing problem in order to minimize both energy consumption and the cycle time and developed a Pareto artificial bee colony algorithm. Using a hybrid Pareto grey wolf optimization, Zikai Zhang, Tang and Zhang [152] solved the balancing problem with the aim of minimizing the carbon emission, the noise emission, and the cycle time. The robot energy consumption was evaluated in order to find the related carbon emissions. B. Zhang and Xu [153] proposed a flower pollination-based algorithm to minimize both the smoothness index and energy consumption.

A cellular strategy-based genetic algorithm was used to solve the problem of minimizing energy consumption and of maximizing the system efficiency in the mixed-model assembly line [154], whereas an improved whale optimization algorithm was proposed to concurrently minimize energy consumption, the smoothness index and the total cost in the semi-automated assembly line designing problem [155].

Three objectives, i.e., the minimization of the cycle time, the minimization of the sum of energy consumption, and the minimization of the total cost were considered in the balancing problem of a multi-robot cooperative assembly line [156]. The authors developed and used a multi-objective hybrid imperialist competitive algorithm with a nondominated sorting strategy.

Energy consumption of a two-sided robotic assembly line was investigated in [157]. In this work, a mixed-integer programming model was proposed with the aim of minimizing energy consumption and the cycle time, and a restarted simulated annealing algorithm was developed to address it.

\section{Policies and Strategies for Energy-Saving}

As shown in the previous section, energy efficiency can be achieved by properly selecting process parameters and with energy-oriented scheduling.

Moreover, policies and strategies for energy-saving can be useful tools for incrementing energy efficiency, reducing energy consumption and costs, and decrementing the carbon footprint.

As argued by Frigerio et al. [158], the energy-efficient control policies can be ranked in buffer-based policies and time-based policies; the class depends on the information used by the policy. 


\subsection{Buffer-Based Policies}

G. Chen et al. [159] applied energy-efficient policies based on a buffer threshold in a Bernoulli serial line and characterized by buffer stripping.

In [160], upstream, downstream, and upstream and downstream policies were investigated in a production line in order to evaluate the energy saving. These policies for changing machine states consider information respectively from upstream, downstream, and simultaneously both upstream and downstream buffers. Zhiyang Jia et al. [161,162] applied the buffer-based policy to switch on/off machines in Bernoulli serial production line. A fuzzy Petri net was used to reduce the idle period by switching off/on the machines [163]. The state commutation is defined by a fuzzy controller evaluating the real-time buffer occupancy and machine status. The results show that the approach proposed reduces energy consumption with a limited throughput loss.

A fuzzy decision method to control the machine switch on/off considering the information regarding the pieces in the buffer and the machine states was studied in [164-166]. Junfeng Wang, Fei, Chang and Li [167] proposed a dynamic adaptive fuzzy reasoning Petri net to establish the machine state. The fuzzy rules were defined considering the upstream and downstream buffer levels and the certainty factor of the rules dynamically changes depending on the production rate.

\subsection{Time-Based Policies}

Mouzon et al. [168] showed the possibility of energy saving by turning off underutilized machines and proposed a machine controller that aims to reduce energy consumption using dispatching rules. Furthermore, supporting the energy savings obtained with the controller, the authors developed a mathematical scheduling model to minimize energy consumption and total completion time.

Frigerio and Matta [169] proposed a switch-off policy based on the time threshold, i.e., the machine shut down after an interval since the last departure. In [170], the authors extended the energy-efficient control strategy defining the switching policy that establishes the commutation between machine states (from on to off and vice versa) according to a specific time interval; special cases of the switching policy were presented. An approach based on online arrival evaluation was studied in order to provide optimal time thresholds of the time-based control policy [171]. Squeo et al. [172] presented the multi-sleep policy, i.e., an extension of the switching policy that uses time thresholds to change the state of the machine components.

\subsection{Hybrid Buffer and Time Based Policies}

Frigerio and Matta [173] presented a control policy, based simultaneously on buffer and time information, that is called TNT policy; this new strategy turns off the machine when the buffer is empty and after a defined time interval from the last departure. The machine switches on, instead, when the threshold of the queue or of the time is reached. Other special cases of the policy were also analyzed. In [174] the TNT policy was applied in a production line with finite buffer capacities. In the context of the pull production line, Renna [175] developed a switch-off policy that uses the downstream buffer level and the customer satisfaction to commute the machine state. Stochastic factor and buffer utilization were considered to evaluate the energy saving opportunity with machine shut down [176]. A fuzzy controller was used to switch the machine on and off in a one buffer one machine manufacturing system [177]. The required production rate, the buffer level, and the state of the machine were considered as input of the fuzzy logic module.

\subsection{Other Policies and Strategies}

In $[178,179]$, a "just-for-peak" buffer inventory policy was developed in order to reduce the energy demand during peak periods. The proposed policy introduced additional buffers, coupled with the standard ones, which are filled during the non-peak period. The "just-for-peak" buffers allow switching off of the upstream machines during the peak 
electricity demand without compromising the throughput. Evaluating the energy efficiency of the machine tool is an important issue for production sustainability. Hu et al. [180] proposed an online monitoring approach to measure energy efficiency. The method proposed by the authors does not require any sensor and, for this reason, the implementation cost is low. The real-time information enables energy efficiency improvement through corrective and immediate actions. Diaz et al. [181] developed a control strategy to reduce energy consumption in a manufacturing system. The authors studied the use of the receding horizon approach to switching on/off early the peripheral devices considering their dynamic with the aim of reducing the global energy consumption. Chang et al. [182] focused on the energy saving opportunity in a serial production line; the authors defined the opportunity window as the maximum possible inactive time of a station that does not involve a reduction of productivity at the end-of-line station. Energy opportunity windows and energy profit bottleneck, i.e., the machine that results in the greatest profit loss on the line, were investigated in [183,184]. Zou et al. [185] provided an approach for evaluating the opportunity windows to reduce energy saving and to perform preventive maintenance in stochastic production systems. The reduction of energy consumption using energy saving opportunity in a multistage manufacturing system was investigated in [186]. In [187], a max-plus algebraic method was used to evaluate the energy saving window in order to switch off the machines in a serial production line. Mashaei and Lennartson [188] defined suitable conditions for switching off machines and included them in a mathematical model with the objective of minimization of energy consumption in the context of a pallet-constrained flow shop. Renna and Materi [189] developed switch-off policies based on workload approaches to achieve energy saving in a job-shop context.

\section{Renewable Energy Sources in Manufacturing Systems}

The integration of renewable energy sources in manufacturing allows reducing the carbon footprint and together, with energy efficiency, leads to sustainable manufacturing. Materi et al. [190] proposed a mathematical model in which the objective function is the maximization of the profit, considering that the manufacturing system, composed of one computer numerical control machine, is supplied by the electric grid and by a photovoltaic (PV) system. The addition of energy storage and its effects were subsequently studied in [191]. Abikarram and McConky [192] investigated the possibility of smoothing load profile to improve the use of the photovoltaic system. The authors claimed that the smoothing strategies allow reducing the effects of introducing the renewable energy source on the net demand variability and supporting the installation of the photovoltaic plant in the manufacturing system. Beier et al. [193] suggested using the batteries of the electric vehicle to improve the integration of the variable renewable energy sources in manufacturing. The results show that, whereas stationary batteries are characterized by continuous availability, the vehicle batteries are independent from the integration of the renewable energy source due to their traction uses. In the paper, it also showed that energy flexibility further improves the variable renewable energy sources' integration. An energy flexibility approach based on real-time control to align the energy demand to on-site renewable energy supply was proposed in [194] without negative influence on the throughput. The method proposed leads to a more efficient integration of renewable sources in the context of a manufacturing system with several processes and intermediate buffers.

Schulze et al. [195] focused on the introduction of battery storage with the aims of improving the use of variable renewable energy sources. Energy storage systems and the energy management lead to an optimal energy self-sufficiency and, at the same time, a high productivity.

A procedure to integrate renewable energy sources applying energy-flexibility was studied in [196]. Popp et al. [197] presented a real-time control approach that considers the renewable energy supply to plan the use of machine tool components characterized by energy-flexibility. The approach was implemented in a manufacturing system composed of thirty machines, with on-site renewable sources in order to evaluate the economic gain. 
Biel et al. [198] investigated the scheduling problem of a flow shop with an onsite wind power supply. The approach consisted of the generation of several power wind scenarios, which were considered after a two-stage stochastic optimization. The first stage allowed obtainment of the optimal production schedule in order to simultaneously minimize the total weighted flow time and the expected energy cost, whereas the second stage fixed the energy supply decision according to the wind power data. Santana-Viera et al. [199] suggested using wind turbines and photovoltaic units to support facilities in interruptible and curtailable demand response programs and proposed a stochastic programming model to define the optimal capacity of the renewable energy sources, in order to maximize the annual utility saving.

A single machine scheduling model was developed in [200] to minimize the total carbon emissions considering renewable energy. The single machine scheduling with renewable energy sources problem was also studied in [201]. In this work, C.-H. Liu developed two models; in the first, the objective was the simultaneous minimization of the total weighted flow time and the carbon emissions, whereas in the second case, the objective function was the minimization of the total flow time while the $\mathrm{CO}_{2}$ emissions were a constraint. C.-H. Liu [202] focused on the discrete lot-sizing and scheduling problem with renewable energy and provided two models: the first considers the simultaneous minimization of the earliness tardiness and $\mathrm{CO}_{2}$ emissions; the second assumes earliness tardiness as optimization function and $\mathrm{CO}_{2}$ emissions as a constraint. Fattahi et al. [203] focused on the mining supply chain and proposed a multi-stage stochastic program including strategic and tactical planning with wind and solar energy supplies. A mixed integer linear programming model considering a wind turbine integrated with the electrical grid was provided in [204]. The manufacturing system is a flow line and the objective function is the minimization of the expected total energy cost. Still focused on the flow shop scheduling problem, Shasha Wang et al. [205] proposed a two-stage multi-objective program considering energy provided by the electrical grid, on-site renewable energy sources, and energy storage. In the first step, the production schedule was defined in order to minimize the total weighted completion time, whereas the second phase consisted of the energy supply decisions with the objective of minimizing the energy costs. Fazli Khalaf and Wang [206] focused on the energy costs in the flow shop scheduling problem with intermittent renewable, energy storage, and real-time electrical price. The authors addressed the problem in two phases. The first phase resulted in the production schedule and the optimal electricity demand curve in order to minimize the purchased electricity, considering the day-ahead electrical tariff and the forecasted renewable energy supply. The second stage concerns aligning the forecasted and the real energy supplied by the renewable energy sources and minimizing the real-time energy cost. A mathematical model with the objective of minimizing the levelized cost of energy by properly sizing a wind turbine, photovoltaic, and battery storage in the context of a multi-stage flow shop in island mode was proposed in [207]. Subramanyam et al. [208] focused simultaneously on defining the size capacity of renewable energy sources and on a production schedule with the aim of minimizing the levelized cost of energy in a flow shop manufacturing system. Xiuli Wu et al. [209] investigated the multi-objective scheduling problem in the context of a flexible flow shop with renewable energy sources. The minimization of electricity cost, under the time-of-use electrical tariff, was considered as the objective function in the scheduling problem of a hybrid flow shop connected to the electrical grid and with an onsite photovoltaic system [210]. A dynamic load scheduling algorithm for the demand side management aiming to minimize the total electricity cost with controlled order delay was investigated in the context of a job shop equipped with an onsite windmill [211]. Cui et al. [212] developed a scheduling model in a manufacturing system with an onsite microgrid system with the target of minimizing the total energy cost by cutting the peak power load and reducing the energy bought from the electrical grid. In this paper, the manufacturing system was defined as a Bernoulli serial line. 


\section{Energy Efficiency Approaches}

The literature is rich in work regarding energy efficiency in manufacturing systems.

The following figure (Figure 4) presents an overview of the main approaches used. The list in the figure of the mathematical method and the used approach is not exhaustive but limited to the papers investigated in this review. The approaches analyzed are grouped in classes although they are not original and are used only to evaluate a new method. For these reasons, an article can be classified into more than one class. Two colorbars were used to show the number of papers respectively in each approach and in each subclass. The "Type of approach colorbar" denotes the number or papers for the main approach (first level), while the "Subclasses colorbar" denotes the number of papers in each subclass of the main approaches (second, third, and fourth levels).

Most of the work approaches are heuristic and metaheuristic. In literature, there are several papers that focused on energy-efficient scheduling and scholars developed and extended different models that can be applied to real-life problems. Mathematical programming models can generate optimal solutions for small-scale multi-objective scheduling problems, but it is difficult to apply to large-scale problems because of their high complexity. Therefore, heuristics and meta-heuristics are proposed to solve large instances and multi-objective scheduling problems. The most common metaheuristic algorithms adopted are the evolutionary and the computational swarm intelligence algorithms. Regarding the evolutionary algorithm, the genetic algorithm, and its subclass NSGA-II, wide applications are found in the literature. Algorithms based on evolution and natural animal and human behavior are widely reported in the literature; thus, the development of hybrid algorithms is common in order to provide a new method with the strength of the native ones.

In the following table (Table 1) the abbreviated name of the algorithms presented in Figure 4 is reported.

Several studies used the exact and numerical approach. In particular, a significant number of works use the mathematical solvers offered by different software due to the high quality of solutions obtained. As previously stated, the exact and numerical approaches require high computational complexity and solution time; for these reasons, the application is restricted to the small scale instances problems.

Simulations, real-time data acquirement, and experimental tests were used to develop, implement, and evaluate energy-efficient strategies. Discrete event simulations were used mainly and compared to the time-continuous simulations; in this review, discrete event and time continuous simulations were grouped because in many cases, simulative approaches used both events or a hybridized approach. Other theories were limitedly studied, but among these, a larger number of works concerns Markov chain and Fuzzy Theory. Few papers regarding approximation strategies were presented in the energy-efficient context.

Table 1. Algorithm abbreviations.

\begin{tabular}{cccc}
\hline ABC & Artificial Bee Colony & MFOA & Moth Flame Optimization Algorithm \\
\hline ACA & ant colony algorithm & MOEA/D & multi-objective evolutionary algorithm based \\
on decomposition \\
AGA & adaptive genetic algorithm & NEH & nawaz-enscore-ham heuristic \\
AMOSA & archived multi-objective simulated annealing & NRGA & non-dominated ranked genetic algorithm \\
BA & bat algorithm & NSGA-II & non-dominated sorting genetic algorithm ii \\
CGA & cellular genetic algorithm & PSO & particle swarm optimization \\
rNGA & domination number-based genetic algorithm & RKGA & RNS \\
FFOA & fruit fly optimization algorithm & RSA & restarted simulated annealing \\
FPA & flower pollination algorithm & SPEA-II & strength pareto evolutionary algorithm ii \\
GGA & grouping genetic algorithm & SPGA-II & sub population genetic algorithm ii \\
GWOA & grey wolf optimization algorithm & VNS & variable neighborhood search \\
ICA & imperialist competitive algorithm & WOA & whale optimization algorithm \\
MBO & migrating bird optimization & WWO & water wave optimization
\end{tabular}




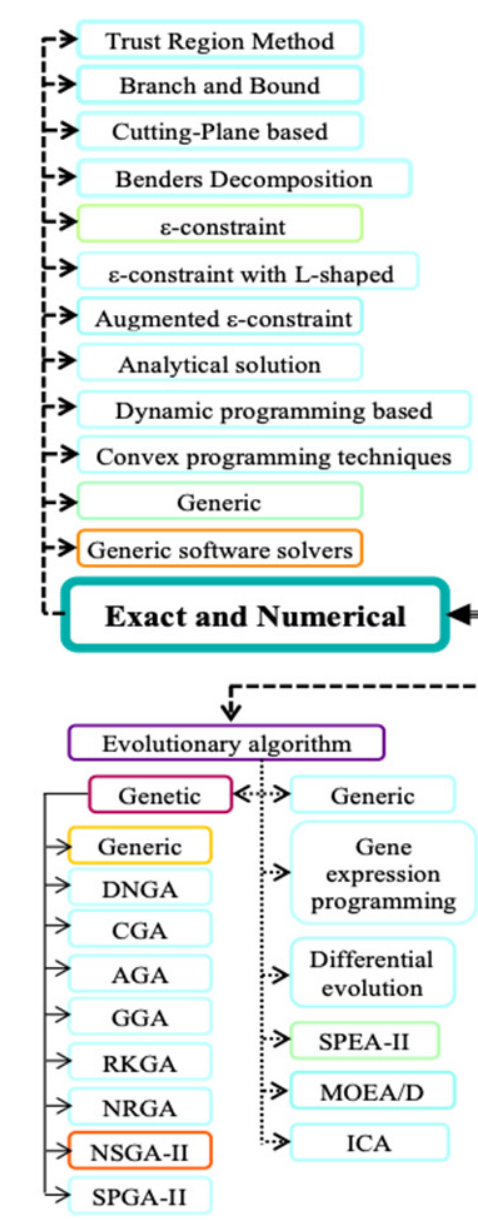

Type of Approach colorbar
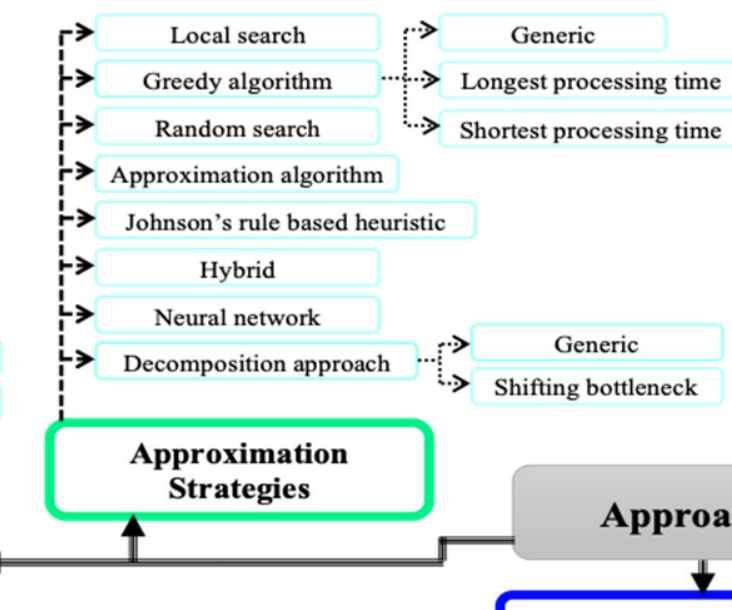

\section{Heuristic/Metaheuristic}

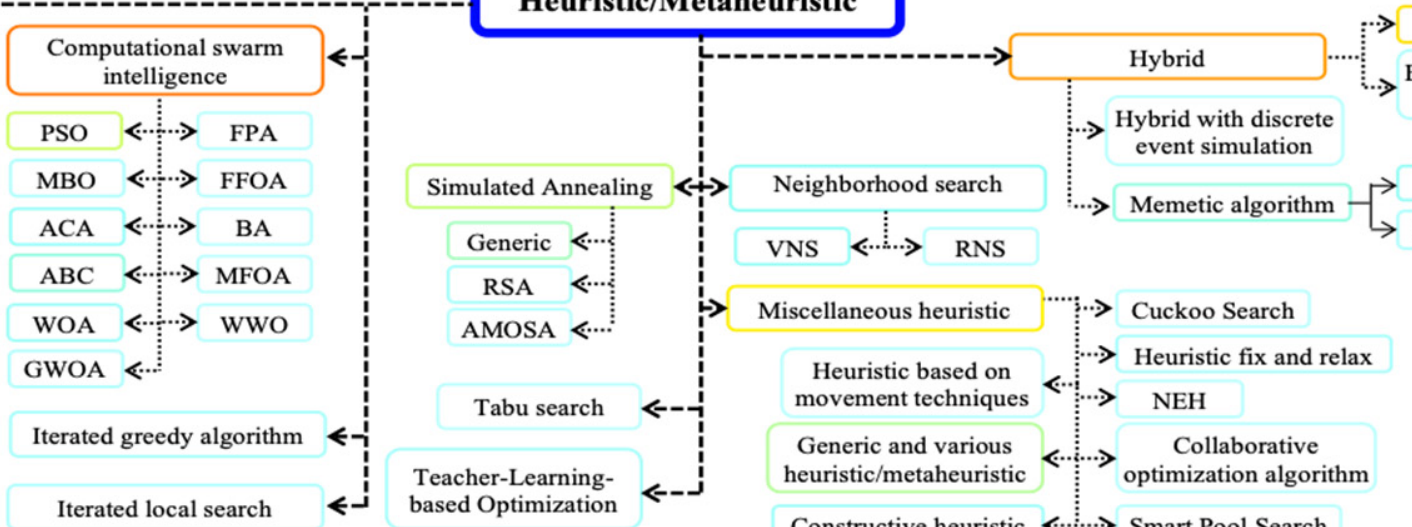
Iterated local search

Subclasses colorbar

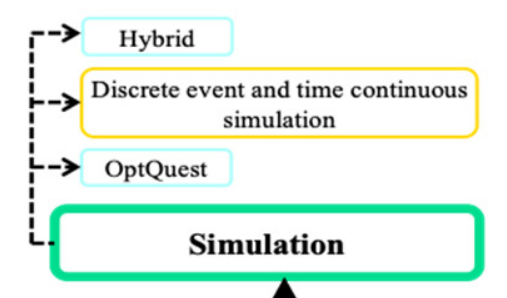

Other Theories$$
4
$$

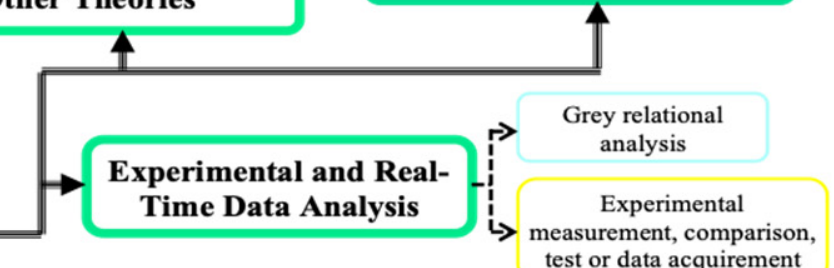
measurement, comparison,
test or data acquirement
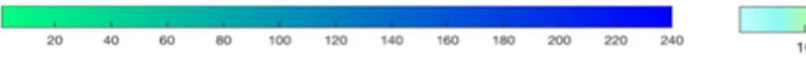

Figure 4. Energy efficient approaches. 


\section{Conclusions and Implications for Future Research}

The growing attention in sustainable manufacturing and reduction of $\mathrm{CO}_{2}$ emissions in order to mitigate climate change has increased the number of papers regarding energy efficiency and the implementation of renewable energy sources in manufacturing.

This review aims to present the works regarding energy efficiency, sustainability, and renewable energy sources in manufacturing, exploring, and deepening the approaches proposed by the scholars in several manufacturing system typologies. The energy efficiency in manufacturing systems was widely analyzed, with about $64 \%$ of the papers considered in this review concerning this topic. The higher number of articles in this context examined the flow shop configuration. Respecting the other works in the manufacturing system group, a significant number of articles analyzed job shops and single machines. Energy efficiency in open shops had limited analyzation, covering only $1 \%$ of the total papers. Moreover, these studies considered the open shop layout in processor environments and not in a typical manufacturing system.

The state of the art system is rich in works that implement and develop heuristic and metaheuristic approaches, especially evolutionary algorithms. The main reason is the great number of articles regarding scheduling problems that require heuristic techniques to be applied in real life and large instance cases. A limited number of articles proposed the application of other theories, for example fuzzy theory. Furthermore, only about $12 \%$ of the analyzed articles focused on the implementation of renewable energy sources in manufacturing. A lack of works was found regarding the development of energy-saving policies that consider renewable energy sources. Whereas energy efficiency in assembly systems was analyzed, the implementation of renewables in this context has not been studied. Energy efficient scheduling, with the integration of renewable energy sources in manufacturing system, needs to be further investigated, particularly in manufacturing systems that were scarcely examined (e.g., open shop, cellular, and reconfigurable manufacturing system).

Future directions and challenges for researchers may be the implementation of energysaving policies, considering the availability of renewable energy supply, in-depth analyses of other and noncommon theories applied in different contexts, and considering renewables and energy efficiency as one target for sustainability and not as separate issues. A relevant future work concerns the scheduling of manufacturing systems with the integration of renewable energy sources, such as photovoltaic, wind, etc.

Author Contributions: S.M. performed the experiments and wrote the paper, and P.R. designed the experiments and revised the paper. All authors have read and agreed to the published version of the manuscript.

Funding: This research received no external funding.

Institutional Review Board Statement: Not applicable.

Informed Consent Statement: Not applicable.

Conflicts of Interest: The authors declare no conflict of interest.

\section{References}

1. IRENA. Global Energy Transformation: A Roadmap to 2050. Global Energy Transformation. A Roadmap to 2050. 2019. Available online: https://www.irena.org/-/media/Files/IRENA/Agency/Publication/2019/Apr/IRENA_Global_Energy_ Transformation_2019.pdf (accessed on 24 May 2021).

2. IRENA. Reaching Zero with Renewables: Eliminating CO2 Emissions from Industry and Transport in Line with the $1.5^{\circ} \mathrm{C}$ Climate Goal. 2020. Available online: https://www.irena.org/publications/2020/Sep/Reaching-Zero-with-Renewables (accessed on 24 May 2021).

3. Watkiss, P.; Downing, T.; Handley, C.; Butterfield, R. The Impacts and Costs of Climate Change. In Modelling Support for Future Actions-Benefits and Cost of Climate Change Policies and Measures; (Report prepared for the DG Environment EC Brussels; Stockholm Environment Institute: Oxford, UK, 2005. 
4. Tsemekidi Tzeiranaki, S.; Bertoldi, P.; Paci, D.; Castellazzi, L.; Ribeiro Serrenho, T.; Economidou, M.; Zangheri, P. Energy Consumption and Energy Efficiency trends in the EU-28, 2000-2018. Publications Office of the European Union. 2020. Available online: https:/ / ec.europa.eu/jrc/en/publication/eur-scientific-and-technical-research-reports/energy-consumption-andenergy-efficiency-trends-eu-28-2000-2018 (accessed on 24 May 2021).

5. Ritchie, H.; Roser, M. $\mathrm{CO}_{2}$ and Greenhouse Gas Emissions. Our World in Data. 2020. Available online: https:/ / ourworldindata. org/co2-and-other-greenhouse-gas-emissions (accessed on 24 May 2021).

6. Eurostat. Electricity Price Statistics-Statistics Explained. 2020. Available online: https://ec.europa.eu/eurostat/statisticsexplained/index.php/Electricity_price_statistics (accessed on 24 May 2021).

7. Calvanese, M.L.; Albertelli, P.; Matta, A.; Taisch, M. Analysis of energy consumption in CNC machining centers and determination of optimal cutting conditions. In Proceedings of the Re-Engineering Manufacturing for Sustainability-Proceedings of the 20th CIRP International Conference on Life Cycle Engineering, Singapore, 17-19 April 2013; pp. 227-232. [CrossRef]

8. Albertelli, P.; Keshari, A.; Matta, A. Energy oriented multi cutting parameter optimization in face milling. J. Clean. Prod. 2016, 137, 1602-1618. [CrossRef]

9. Li, C.; Chen, X.; Tang, Y.; Li, L. Selection of optimum parameters in multi-pass face milling for maximum energy efficiency and minimum production cost. J. Clean. Prod. 2017, 140, 1805-1818. [CrossRef]

10. Li, J.; Lu, Y.; Zhao, H.; Li, P.; Yao, Y. Optimization of cutting parameters for energy saving. Int. J. Adv. Manuf. Technol. 2014, 70, 117-124. [CrossRef]

11. Yan, J.; Li, L. Multi-objective optimization of milling parameters-the trade-offs between energy, production rate and cutting quality. J. Clean. Prod. 2013, 52, 462-471. [CrossRef]

12. Chen, X.; Li, C.; Tang, Y.; Li, L.; Du, Y.; Li, L. Integrated optimization of cutting tool and cutting parameters in face milling for minimizing energy footprint and production time. Energy 2019, 175, 1021-1037. [CrossRef]

13. Wang, W.; Tian, G.; Chen, M.; Tao, F.; Zhang, C.; AI-Ahmari, A.; Li, Z.; Jiang, Z. Dual-objective program and improved artificial bee colony for the optimization of energy-conscious milling parameters subject to multiple constraints. J. Clean. Prod. 2020, 245, 118714. [CrossRef]

14. Zhang, T.; Liu, Z.; Sun, X.; Xu, J.; Dong, L.; Zhu, G. Investigation on specific milling energy and energy efficiency in high-speed milling based on energy flow theory. Energy 2020, 192, 116596. [CrossRef]

15. Hanafi, I.; Khamlichi, A.; Cabrera, F.M.; Almansa, E.; Jabbouri, A. Optimization of cutting conditions for sustainable machining of PEEK-CF30 using TiN tools. J. Clean. Prod. 2012, 33, 1-9. [CrossRef]

16. Rajemi, M.F.; Mativenga, P.T.; Aramcharoen, A. Sustainable machining: Selection of optimum turning conditions based on minimum energy considerations. J. Clean. Prod. 2010, 18, 1059-1065. [CrossRef]

17. Wang, Q.; Liu, F.; Wang, X. Multi-objective optimization of machining parameters considering energy consumption. Int. J. Adv. Manuf. Technol. 2014, 71, 1133-1142. [CrossRef]

18. Mori, M.; Fujishima, M.; Inamasu, Y.; Oda, Y. A study on energy efficiency improvement for machine tools. CIRP Ann. Manuf. Technol. 2011, 60, 145-148. [CrossRef]

19. Zhang, Z.; Wu, L.; Jia, S.; Peng, T. Multi-objective parameter optimization to support energy-efficient peck deep-hole drilling processes with twist drills. Int. J. Adv. Manuf. Technol. 2020, 106, 4913-4932. [CrossRef]

20. Jia, S.; Yuan, Q.; Cai, W.; Lv, J.; Hu, L. Establishing prediction models for feeding power and material drilling power to support sustainable machining. Int. J. Adv. Manuf. Technol. 2019, 100, 2243-2253. [CrossRef]

21. Jia, S.; Yuan, Q.; Cai, W.; Yuan, Q.; Liu, C.; Lv, J.; Zhang, Z. Establishment of an improved material-drilling power model to support energy management of drilling processes. Energies 2018, 11, 2013. [CrossRef]

22. Heinzel, C.; Kolkwitz, B. The Impact of fluid supply on energy efficiency and process performance in grinding. CIRP Ann.-Manuf. Technol. 2019, 68, 337-340. [CrossRef]

23. Winter, M.; Li, W.; Kara, S.; Herrmann, C. Determining optimal process parameters to increase the eco-efficiency of grinding processes. J. Clean. Prod. 2014, 66, 644-654. [CrossRef]

24. Jiang, P.; Li, G.; Liu, P.; Jiang, L.; Li, X. Energy consumption model and energy efficiency evaluation for CNC continuous generating grinding machine tools. Int. J. Sustain. Eng. 2017, 10, 226-232. [CrossRef]

25. Li, W.; Winter, M.; Kara, S.; Herrmann, C. Eco-efficiency of manufacturing processes: A grinding case. CIRP Ann. Manuf. Technol. 2012, 61, 59-62. [CrossRef]

26. Mouzon, G.; Yildirim, M.B. A framework to minimise total energy consumption and total tardiness on a single machine. Int. J. Sustain. Eng. 2008, 1, 105-116. [CrossRef]

27. Yildirim, M.B.; Mouzon, G. Single-Machine Sustainable Production Planning to Minimize Total Energy Consumption and Total Completion Time Using a Multiple Objective Genetic Algorithm. IEEE Trans. Eng. Manag. 2012, 59, 585-597. [CrossRef]

28. Shrouf, F.; Ordieres-Meré, J.; García-Sánchez, A.; Ortega-Mier, M. Optimizing the production scheduling of a single machine to minimize total energy consumption costs. J. Clean. Prod. 2014, 67, 197-207. [CrossRef]

29. Wang, S.; Liu, M.; Chu, F.; Chu, C. Bi-objective optimization of a single machine batch scheduling problem with energy cost consideration. J. Clean. Prod. 2016, 137, 1205-1215. [CrossRef]

30. Zhang, S.; Che, A.; Wu, X.; Chu, C. Improved mixed-integer linear programming model and heuristics for bi-objective singlemachine batch scheduling with energy cost consideration. Eng. Optim. 2018, 50, 1380-1394. [CrossRef] 
31. Mansouri, S.A.; Aktas, E.; Besikci, U. Green scheduling of a two-machine flowshop: Trade-off between makespan and energy consumption. Eur. J. Oper. Res. 2016, 248, 772-788. [CrossRef]

32. Mansouri, S.A.; Aktas, E. Minimizing Energy consumption and makespan in a two-machine flowshop scheduling problem. J. Oper. Res. Soc. 2016, 67, 1382-1394. [CrossRef]

33. Fang, K.; Luo, W.; Che, A. Speed scaling in two-machine lot-streaming flow shops with consistent sublots. J. Oper. Res. Soc. 2020. [CrossRef]

34. Assia, S.; El Abbassi, I.; El Barkany, A.; Darcherif, M.; El Biyaali, A. Green Scheduling of Jobs and Flexible Periods of Maintenance in a Two-Machine Flowshop to Minimize Makespan, a Measure of Service Level and Total Energy Consumption. Adv. Oper. Res. 2020, 2020, 9732563. [CrossRef]

35. Wang, S.; Zhu, Z.; Fang, K.; Chu, F.; Chu, C. Scheduling on a two-machine permutation flow shop under time-of-use electricity tariffs. Int. J. Prod. Res. 2018, 56, 3173-3187. [CrossRef]

36. Ho, M.H.; Hnaien, F.; Dugardin, F. Electricity cost minimisation for optimal makespan solution in flow shop scheduling under time-of-use tariffs. Int. J. Prod. Res. 2020, 1-27. [CrossRef]

37. Yan, C.-B. Energy Consumption optimization in Two-Machine Bernoulli Serial Lines with Limits on Machine Efficiency. In Proceedings of the 2019 IEEE 15th International Conference on Automation Science and Engineering (CASE), Vancouver, BC, Canada, 22-26 August 2019; pp. 85-90. [CrossRef]

38. Graham, R.L.; Lawler, E.L.; Lenstra, J.K.; Kan, A.H.G.R. Optimization and approximation in deterministic sequencing and scheduling: A survey. Ann. Discret. Math. 1979, 5, 287-326. [CrossRef]

39. Jia, Z.H.; Zhang, Y.L.; Leung, J.Y.T.; Li, K. Bi-criteria ant colony optimization algorithm for minimizing makespan and energy consumption on parallel batch machines. Appl. Soft Comput. 2017, 55, 226-237. [CrossRef]

40. Rocholl, J.; Mönch, L.; Fowler, J. Bi-criteria parallel batch machine scheduling to minimize total weighted tardiness and electricity cost. J. Bus. Econ. 2020, 90, 1345-1381. [CrossRef]

41. Wang, S.; Wang, X.; Yu, J.; Ma, S.; Liu, M. Bi-objective identical parallel machine scheduling to minimize total energy consumption and makespan. J. Clean. Prod. 2018, 193, 424-440. [CrossRef]

42. Liu, C.-H.; Nanthapodej, R.; Hsu, S.-Y. Scheduling two interfering job sets on parallel machines under peak power constraint. Prod. Eng. 2018, 12, 611-619. [CrossRef]

43. Zhou, S.; Li, X.; Du, N.; Pang, Y.; Chen, H. A multi-objective differential evolution algorithm for parallel batch processing machine scheduling considering electricity consumption cost. Comput. Oper. Res. 2018, 96, 55-68. [CrossRef]

44. Zandi, A.; Ramezanian, R.; Monplaisir, L. Green parallel machines scheduling problem: A bi-objective model and a heuristic algorithm to obtain Pareto frontier. J. Oper. Res. Soc. 2020, 71, 967-978. [CrossRef]

45. Kurniawan, B.; Gozali, A.A.; Weng, W.; Fujimura, S. A genetic algorithm for unrelated parallel machine scheduling minimizing makespan cost and electricity cost under time-of-use (TOU) tariffs with job delay mechanism. In Proceedings of the 2017 IEEE International Conference on Industrial Engineering and Engineering Management (IEEM), Singapore, 10-13 December 2017; pp. 583-587. [CrossRef]

46. Moon, J.-Y.; Shin, K.; Park, J. Optimization of production scheduling with time-dependent and machine-dependent electricity cost for industrial energy efficiency. Int. J. Adv. Manuf. Technol. 2013, 68, 523-535. [CrossRef]

47. Saberi-Aliabad, H.; Reisi-Nafchi, M.; Moslehi, G. Energy-efficient scheduling in an unrelated parallel-machine environment under time-of-use electricity tariffs. J. Clean. Prod. 2020, 249, 119393. [CrossRef]

48. $\mathrm{Wu}, \mathrm{X}$.; Che, A. A memetic differential evolution algorithm for energy-efficient parallel machine scheduling. Omega 2019, 82, 155-165. [CrossRef]

49. Pan, Z.; Lei, D.; Zhang, Q. A New Imperialist Competitive Algorithm for Multiobjective Low Carbon Parallel Machines Scheduling. Math. Probl. Eng. 2018, 2018, 5914360. [CrossRef]

50. Meng, L.; Zhang, C.; Shao, X.; Ren, Y.; Ren, C. Mathematical modelling and optimisation of energy-conscious hybrid flow shop scheduling problem with unrelated parallel machines. Int. J. Prod. Res. 2019, 57, 1119-1145. [CrossRef]

51. Cota, L.P.; Coelho, V.N.; Guimarães, F.G.; Souza, M.J. Bi-criteria formulation for green scheduling with unrelated parallel machines with sequence-dependent setup times. Int. Trans. Oper. Res. 2021, 28, 996-1017. [CrossRef]

52. Zhang, H.; Wu, Y.; Pan, R.; Xu, G. Two-stage parallel speed-scaling machine scheduling under time-of-use tariffs. J. Intell. Manuf. 2021, 32, 91-112. [CrossRef]

53. Zhang, H.; Zhao, F.; Fang, K.; Sutherland, J.W. Energy-conscious flow shop scheduling under time-of-use electricity tariffs. CIRP Ann. Manuf. Technol. 2014, 63, 37-40. [CrossRef]

54. Nagasawa, K.; Ikeda, Y.; Irohara, T. Robust flow shop scheduling with random processing times for reduction of peak power consumption. Simul. Model. Pract. Theory 2015, 59, 102-113. [CrossRef]

55. Liu, G.-S.; Yang, H.-D.; Cheng, M.-B. A three-stage decomposition approach for energy-aware scheduling with processing-timedependent product quality. Int. J. Prod. Res. 2017, 55, 3073-3091. [CrossRef]

56. Liu, G.-S.; Zhou, Y.; Yang, H.-D. Minimizing energy consumption and tardiness penalty for fuzzy flow shop scheduling with state-dependent setup time. J. Clean. Prod. 2017, 147, 470-484. [CrossRef]

57. Zhou, B.; Liu, W. Energy-efficient multi-objective scheduling algorithm for hybrid flow shop with fuzzy processing time. Proc. Inst. Mech. Eng. Part I J. Syst. Control Eng. 2019, 233, 1282-1297. [CrossRef] 
58. Chen, G.; Zhang, L.; Arinez, J.; Biller, S. Energy-Efficient Production Systems through Schedule-Based Operations. IEEE Trans. Autom. Sci. Eng. 2013, 10, 27-37. [CrossRef]

59. Masmoudi, O.; Yalaoui, A.; Ouazene, Y.; Chehade, H. Lot-sizing in flow-shop with energy consideration for sustainable manufacturing systems. IFAC Pap. 2015, 28, 727-732. [CrossRef]

60. Masmoudi, O.; Yalaoui, A.; Ouazene, Y.; Chehade, H. Lot-sizing in a multi-stage flow line production system with energy consideration. Int. J. Prod. Res. 2017, 55, 1640-1663. [CrossRef]

61. Masmoudi, O.; Yalaoui, A.; Ouazene, Y.; Chehade, H. Solving a capacitated flow-shop problem with minimizing total energy costs. Int. J. Adv. Manuf. Technol. 2017, 90, 2655-2667. [CrossRef]

62. Masmoudi, O.; Yalaoui, A.; Ouazene, Y.; Chehade, H. Multi-item capacitated lot-sizing problem in a flow-shop system with energy consideration. IFAC Pap. 2016, 49, 301-306. [CrossRef]

63. Pinedo, M.L. Scheduling: Theory, algorithms, and systems. In Scheduling: Theory 2008, Algorithms, and Systems; Springer: New York, NY, USA, 2008. [CrossRef]

64. Han, Y.; Li, J.; Sang, H.; Liu, Y.; Gao, K.; Pan, Q. Discrete evolutionary multi-objective optimization for energy-efficient blocking flow shop scheduling with setup time. Appl. Soft Comput. 2020, 93, 106343. [CrossRef]

65. Renna, P.; Materi, S. Design model of flow lines to include switch-off policies reducing energy consumption. Appl. Sci. 2020, 10, 1475. [CrossRef]

66. Potts, C.N.; Shmoys, D.B.; Williamson, D.P. Permutation vs. non-permutation flow shop schedules. Oper. Res. Lett. 1991, 10, 281-284. [CrossRef]

67. Fang, K.; Uhan, N.A.; Zhao, F.; Sutherland, J.W. Flow shop scheduling with peak power consumption constraints. Ann. Oper. Res. 2013, 206, 115-145. [CrossRef]

68. Jiang, E.; Wang, L. An improved multi-objective evolutionary algorithm based on decomposition for energy-efficient permutation flow shop scheduling problem with sequence-dependent setup time. Int. J. Prod. Res. 2019, 57, 1756-1771. [CrossRef]

69. Lu, C.; Gao, L.; Li, X.; Pan, Q.; Wang, Q. Energy-efficient permutation flow shop scheduling problem using a hybrid multi-objective backtracking search algorithm. J. Clean. Prod. 2017, 144, 228-238. [CrossRef]

70. Öztop, H.; Tasgetiren, M.F.; Eliiyi, D.T.; Pan, Q.K.; Kandiller, L. An energy-efficient permutation flowshop scheduling problem. Expert Syst. Appl. 2020, 150, 113279. [CrossRef]

71. Utama, D.M.; Widodo, D.S.; Ibrahim, M.F.; Hidayat, K.; Baroto, T.; Yurifah, A. The hybrid whale optimization algorithm: A new metaheuristic algorithm for energy-efficient on flow shop with dependent sequence setup. J. Phys. Conf. Ser. 2020, 1569, 022094. [CrossRef]

72. $\mathrm{Wu}, \mathrm{X}$.; Che, A. Energy-efficient no-wait permutation flow shop scheduling by adaptive multi-objective variable neighborhood search. Omega 2020, 94, 102117. [CrossRef]

73. Yüksel, D.; Taşgetiren, M.F.; Kandiller, L.; Gao, L. An energy-efficient bi-objective no-wait permutation flowshop scheduling problem to minimize total tardiness and total energy consumption. Comput. Ind. Eng. 2020, 145, 106431. [CrossRef]

74. Naderi, B.; Ruiz, R. The distributed permutation flowshop scheduling problem. Comput. Oper. Res. 2010, 37, 754-768. [CrossRef]

75. Chen, J.; Wang, L.; Peng, Z. A collaborative optimization algorithm for energy-efficient multi-objective distributed no-idle flow-shop scheduling. Swarm Evol. Comput. 2019, 50, 100557. [CrossRef]

76. Wang, J.-J.; Wang, L. A Knowledge-Based Cooperative Algorithm for Energy-Efficient Scheduling of Distributed Flow-Shop. IEEE Trans. Syst. Man Cybern. Syst. 2020, 50, 1805-1819. [CrossRef]

77. Bruzzone, A.A.; Anghinolfi, D.; Paolucci, M.; Tonelli, F. Energy-aware scheduling for improving manufacturing process sustainability: A mathematical model for flexible flow shops. CIRP Ann. Manuf. Technol. 2012, 61, 459-462. [CrossRef]

78. Dai, M.; Tang, D.; Giret, A.; Salido, M.A.; Li, W.D. Energy-efficient scheduling for a flexible flow shop using an improved genetic-simulated annealing algorithm. Robot. Comput. Integr. Manuf. 2013, 29, 418-429. [CrossRef]

79. Luo, H.; Du, B.; Huang, G.Q.; Chen, H.; Li, X. Hybrid flow shop scheduling considering machine electricity consumption cost. Int. J. Prod. Econ. 2013, 146, 423-439. [CrossRef]

80. Gong, G.; Chiong, R.; Deng, Q.; Han, W.; Zhang, L.; Lin, W.; Li, K. Energy-efficient flexible flow shop scheduling with worker flexibility. Expert Syst. Appl. 2020, 141, 112902. [CrossRef]

81. Huang, R.-H.; Yu, S.-C.; Chen, P.-H. Energy-Saving Scheduling in a Flexible Flow Shop Using a Hybrid Genetic Algorithm. J. Environ. Prot. 2017, 8, 1037-1056. [CrossRef]

82. Hasani, A.; Hosseini, S.M.H. A bi-objective flexible flow shop scheduling problem with machine-dependent processing stages: Trade-off between production costs and energy consumption. Appl. Math. Comput. 2020, 386, 125533. [CrossRef]

83. Luo, J.; Fujimura, S.; El Baz, D.; Plazolles, B. GPU based parallel genetic algorithm for solving an energy efficient dynamic flexible flow shop scheduling problem. J. Parallel Distrib. Comput. 2019, 133, 244-257. [CrossRef]

84. Tang, D.; Dai, M.; Salido, M.A.; Giret, A. Energy-efficient dynamic scheduling for a flexible flow shop using an improved particle swarm optimization. Comput. Ind. 2016, 81, 82-95. [CrossRef]

85. Nasiri, M.M.; Abdollahi, M.; Rahbari, A.; Salmanzadeh, N.; Salesi, S. Minimizing the energy consumption and the total weighted tardiness for the flexible flowshop using NSGA-II and NRGA. J. Ind. Syst. Eng. 2018, 11, 150-162.

86. Yan, J.; Li, L.; Zhao, F.; Zhang, F.; Zhao, Q. A multi-level optimization approach for energy-efficient flexible flow shop scheduling. J. Clean. Prod. 2016, 137, 1543-1552. [CrossRef] 
87. Zhang, M.; Yan, J.; Zhang, Y.; Yan, S. Optimization for energy-efficient flexible flow shop scheduling under time of use electricity tariffs. Procedia CIRP 2019, 80, 251-256. [CrossRef]

88. Zeng, Z.; Hong, M.; Man, Y.; Li, J.; Zhang, Y.; Liu, H. Multi-object optimization of flexible flow shop scheduling with batch process-Consideration total electricity consumption and material wastage. J. Clean. Prod. 2018, 183, 925-939. [CrossRef]

89. Lei, D.; Gao, L.; Zheng, Y. A novel teaching-learning-based optimization algorithm for energy-efficient scheduling in hybrid flow shop. IEEE Trans. Eng. Manag. 2018, 65, 330-340. [CrossRef]

90. Chen, T.-L.; Cheng, C.-Y.; Chou, Y.-H. Multi-objective genetic algorithm for energy-efficient hybrid flow shop scheduling with lot streaming. Ann. Oper. Res. 2020, 290, 813-836. [CrossRef]

91. Jiang, S.; Zhang, L. Energy-Oriented Scheduling for Hybrid Flow Shop With Limited Buffers Through Efficient Multi-Objective Optimization. IEEE Access 2019, 7, 34477-34487. [CrossRef]

92. Li, J.; Sang, H.; Han, Y.; Wang, C.; Gao, K. Efficient multi-objective optimization algorithm for hybrid flow shop scheduling problems with setup energy consumptions. J. Clean. Prod. 2018, 181, 584-598. [CrossRef]

93. Schulz, S.; Buscher, U.; Shen, L. Multi-objective hybrid flow shop scheduling with variable discrete production speed levels and time-of-use energy prices. J. Bus. Econ. 2020, 90, 1315-1343. [CrossRef]

94. Schulz, S.; Neufeld, J.S.; Buscher, U. A multi-objective iterated local search algorithm for comprehensive energy-aware hybrid flow shop scheduling. J. Clean. Prod. 2019, 224, 421-434. [CrossRef]

95. Kemmoe, S.; Lamy, D.; Tchernev, N. Job-shop like manufacturing system with variable power threshold and operations with power requirements. Int. J. Prod. Res. 2017, 55, 6011-6032. [CrossRef]

96. Tang, D.; Dai, M. Energy-efficient approach to minimizing the energy consumption in an extended job-shop scheduling problem. Chin. J. Mech. Eng. 2015, 28, 1048-1055. [CrossRef]

97. Escamilla, J.; Salido, M.A.; Giret, A.; Barber, F. A metaheuristic technique for energy-efficiency in job-shop scheduling. Knowl. Eng. Rev. 2016, 31, 475-485. [CrossRef]

98. Salido, M.A.; Escamilla, J.; Giret, A.; Barber, F. A genetic algorithm for energy-efficiency in job-shop scheduling. Int. J. Adv. Manuf. Technol. 2016, 85, 1303-1314. [CrossRef]

99. Yin, L.; Li, X.; Gao, L.; Lu, C.; Zhang, Z. Energy-efficient job shop scheduling problem with variable spindle speed using a novel multi-objective algorithm. Adv. Mech. Eng. 2017, 9, 1687814017695959. [CrossRef]

100. Masmoudi, O.; Delorme, X.; Gianessi, P. Job-shop scheduling problem with energy consideration. Int. J. Prod. Econ. 2019, 216, 12-22. [CrossRef]

101. Zhang, R.; Chiong, R. Solving the energy-efficient job shop scheduling problem: A multi-objective genetic algorithm with enhanced local search for minimizing the total weighted tardiness and total energy consumption. J. Clean. Prod. 2016, 112, 3361-3375. [CrossRef]

102. May, G.; Stahl, B.; Taisch, M.; Prabhu, V. Multi-objective genetic algorithm for energy-efficient job shop scheduling. Int. J. Prod. Res. 2015, 53, 7071-7089. [CrossRef]

103. Nie, L.; Wang, X.; Pan, F. A game-theory approach based on genetic algorithm for flexible job shop scheduling problem. J. Phys. Conf. Ser. 2019, 1187, 32095. [CrossRef]

104. Wang, H.; Jiang, Z.; Wang, Y.; Zhang, H.; Wang, Y. A two-stage optimization method for energy-saving flexible job-shop scheduling based on energy dynamic characterization. J. Clean. Prod. 2018, 188, 575-588. [CrossRef]

105. Lei, D.; Li, M.; Wang, L. A Two-Phase Meta-Heuristic for Multiobjective Flexible Job Shop Scheduling Problem With Total Energy Consumption Threshold. IEEE Trans. Cybern. 2019, 49, 1097-1109. [CrossRef]

106. Renna, P. Peak electricity demand control of manufacturing systems by Gale-Shapley algorithm with discussion on open innovation engineering. J. Open Innov. Technol. Mark. Complex. 2020, 6, 29. [CrossRef]

107. Ebrahimi, A.; Jeon, H.W.; Lee, S.; Wang, C. Minimizing total energy cost and tardiness penalty for a scheduling-layout problem in a flexible job shop system: A comparison of four metaheuristic algorithms. Comput. Ind. Eng. 2020, 141, 106295. [CrossRef]

108. Abedi, M.; Chiong, R.; Noman, N.; Zhang, R. A multi-population, multi-objective memetic algorithm for energy-efficient job-shop scheduling with deteriorating machines. Expert Syst. Appl. 2020, 157, 113348. [CrossRef]

109. Zhang, L.; Li, Z.; Królczyk, G.; Wu, D.; Tang, Q. Mathematical modeling and multi-attribute rule mining for energy efficient job-shop scheduling. J. Clean. Prod. 2019, 241, 118289. [CrossRef]

110. Jiang, T.; Zhang, C.; Zhu, H.; Gu, J.; Deng, G. Energy-efficient scheduling for a job shop using an improved whale optimization algorithm. Mathematics 2018, 6, 220. [CrossRef]

111. Jiang, T.; Zhang, C.; Zhu, H.; Deng, G. Energy-Efficient Scheduling for a Job Shop Using Grey Wolf Optimization Algorithm with Double-Searching Mode. Math. Probl. Eng. 2018, 2018, 1-12. [CrossRef]

112. Jiang, E.; Wang, L.; Peng, Z. Solving energy-efficient distributed job shop scheduling via multi-objective evolutionary algorithm with decomposition. Swarm Evol. Comput. 2020, 58, 100745. [CrossRef]

113. Moon, J.-Y.; Park, J. Smart production scheduling with time-dependent and machine-dependent electricity cost by considering distributed energy resources and energy storage. Int. J. Prod. Res. 2014, 52, 3922-3939. [CrossRef]

114. Meng, L.; Zhang, C.; Shao, X.; Ren, Y. MILP models for energy-aware flexible job shop scheduling problem. J. Clean. Prod. 2019, 210, 710-723. [CrossRef]

115. Lei, D.; Zheng, Y.; Guo, X. A shuffled frog-leaping algorithm for flexible job shop scheduling with the consideration of energy consumption. Int. J. Prod. Res. 2017, 55, 3126-3140. [CrossRef] 
116. Luo, S.; Zhang, L.; Fan, Y. Energy-efficient scheduling for multi-objective flexible job shops with variable processing speeds by grey wolf optimization. J. Clean. Prod. 2019, 234, 1365-1384. [CrossRef]

117. Dai, M.; Tang, D.; Giret, A.; Salido, M.A. Multi-objective optimization for energy-efficient flexible job shop scheduling problem with transportation constraints. Robot. Comput. Integr. Manuf. 2019, 59, 143-157. [CrossRef]

118. Mokhtari, H.; Hasani, A. An energy-efficient multi-objective optimization for flexible job-shop scheduling problem. Comput. Chem. Eng. 2017, 104, 339-352. [CrossRef]

119. Wu, X.; Sun, Y. A green scheduling algorithm for flexible job shop with energy-saving measures. J. Clean. Prod. 2018, 172, 3249-3264. [CrossRef]

120. Wang, J.; Liu, Y.; Ren, S.; Wang, C.; Wang, W. Evolutionary game based real-time scheduling for energy-efficient distributed and flexible job shop. J. Clean. Prod. 2021, 293, 126093. [CrossRef]

121. Lawler, E.L.; Luby, M.G.; Vazirani, V.V. Scheduling open shops with parallel machines. Oper. Res. Lett. 1982, 1, 161-164. [CrossRef]

122. Sevastianov, S.V.; Woeginger, G.J. Makespan minimization in open shops: A polynomial time approximation scheme. Math. Program. 1998, 82, 191-198. [CrossRef]

123. Lawler, E.L.; Lenstra, J.K.; Kan, A.H.G.R. Minimizing Maximum Lateness in a Two-Machine Open Shop. Math. Oper. Res. 1981, 6, 153-158. [CrossRef]

124. Kravchenko, S.A. On the complexity of minimizing the number of late jobs in unit time open shop. Discret. Appl. Math. 2000, 100, 127-132. [CrossRef]

125. Galambos, G.; Woeginger, G.J. Minimizing the weighted number of late jobs in UET open shops. ZOR Methods Models Oper. Res. 1995, 41, 109-114. [CrossRef]

126. Achugbue, J.O.; Chin, F.Y. Scheduling the Open Shop to Minimize Mean Flow Time. SIAM J. Comput. 1982, 11, 709-720. [CrossRef]

127. Tautenhahn, T.; Woeginger, G.J. Minimizing the total completion time in a unit-time open shop with release times. Oper. Res. Lett. 1997, 20, 207-212. [CrossRef]

128. Hosseinabadi, A.A.R.; Vahidi, J.; Saemi, B.; Sangaiah, A.K.; Elhoseny, M. Extended Genetic Algorithm for solving open-shop scheduling problem. Soft Comput. 2019, 23, 5099-5116. [CrossRef]

129. Bampis, E.; Letsios, D.; Lucarelli, G. A note on multiprocessor speed scaling with precedence constraints. In Proceedings of the 26th ACM Symposium on Parallelism in Algorithms and Architectures, Prague, Czech Republic, 23-25 June 2014 ; pp. 138-142. [CrossRef]

130. Bampis, E.; Letsios, D.; Lucarelli, G. Green scheduling, flows and matchings. Theor. Comput. Sci. 2015, 579, 126-136. [CrossRef]

131. Niakan, F.; Baboli, A.; Moyaux, T.; Botta-Genoulaz, V. A new bi-objective mathematical model for sustainable dynamic cellular manufacturing systems. In Proceedings of the 2014 IEEE International Conference on Industrial Engineering and Engineering Management, Selangor Darul Ehsan, Malaysia, 9-12 December 2014; pp. 938-942. [CrossRef]

132. Niakan, F.; Baboli, A.; Moyaux, T.; Botta-Genoulaz, V. A bi-objective model in sustainable dynamic cell formation problem with skill-based worker assignment. J. Manuf. Syst. 2016, 38, 46-62. [CrossRef]

133. Imran, M.; Kang, C.; Lee, Y.H.; Jahanzaib, M.; Aziz, H. Cell formation in a cellular manufacturing system using simulation integrated hybrid genetic algorithm. Comput. Ind. Eng. 2017, 105, 123-135. [CrossRef]

134. Iqbal, A.; Al-Ghamdi, K.A. Energy-efficient cellular manufacturing system: Eco-friendly revamping of machine shop configuration. Energy 2018, 163, 863-872. [CrossRef]

135. Saddikuti, V.; Pesaru, V. NSGA Based Algorithm for Energy Efficient Scheduling in Cellular Manufacturing. Procedia Manuf. 2019, 39, 1002-1009. [CrossRef]

136. Lamba, K.; Kumar, R.; Mishra, S.; Rajput, S. Sustainable dynamic cellular facility layout: A solution approach using simulated annealing-based meta-heuristic. Ann. Oper. Res. 2020, 290, 5-26. [CrossRef]

137. Choi, Y.-C.; Xirouchakis, P. A holistic production planning approach in a reconfigurable manufacturing system with energy consumption and environmental effects. Int. J. Comput. Integr. Manuf. 2015, 28, 379-394. [CrossRef]

138. Zhang, J.; Khalgui, M.; Boussahel, W.M.; Frey, G.; Hon, C.; Wu, N.; Li, Z. Modeling and Verification of Reconfigurable and Energy-Efficient Manufacturing Systems. Discret. Dyn. Nat. Soc. 2015, 2015, 1-14. [CrossRef]

139. Liu, M.; An, L.; Zhang, J.; Chu, F.; Chu, C. Energy-oriented bi-objective optimisation for a multi-module reconfigurable manufacturing system. Int. J. Prod. Res. 2019, 57, 5974-5995. [CrossRef]

140. Touzout, F.A.; Benyoucef, L. Multi-objective sustainable process plan generation in a reconfigurable manufacturing environment: Exact and adapted evolutionary approaches. Int. J. Prod. Res. 2019, 57, 2531-2547. [CrossRef]

141. Khezri, A.; Haddou Benderbal, H.; Benyoucef, L. Sustainable Multi-Objective Process Plan Generation in RMS through Modelling Energy Consumption; Benyoucef, L., Ed.; Springer International Publishing: Cham, Switzerland, 2020; pp. 161-177. [CrossRef]

142. Khezri, A.; Haddou Benderbal, H.; Benyoucef, L. Towards a sustainable reconfigurable manufacturing system (SRMS): Multiobjective based approaches for process plan generation problem. Int. J. Prod. Res. 2021, 59, 4533-4558. [CrossRef]

143. Khezri, A.; Haddou Benderbal, H.; Benyoucef, L. A Sustainable Reconfigurable Manufacturing System Designing With Focus On Environmental Hazardous Wastes. In Proceedings of the 2019 24th IEEE International Conference on Emerging Technologies and Factory Automation (ETFA), Zaragoza, Spain, 10-13 September 2019; pp. 317-324. [CrossRef]

144. Abdullah, A.; Ab Rashid, M.F.F.; Ponnambalam, S.G.; Ghazalli, Z. Energy efficient modeling and optimization for assembly sequence planning using moth flame optimization. Assem. Autom. 2019, 39, 356-368. [CrossRef] 
145. Michalos, G.; Fysikopoulos, A.; Makris, S.; Mourtzis, D.; Chryssolouris, G. Multi criteria assembly line design and configurationAn automotive case study. CIRP J. Manuf. Sci. Technol. 2015, 9, 69-87. [CrossRef]

146. Nilakantan, M.J.; Ponnambalam, S.G.; Jawahar, N. Design of energy efficient RAL system using evolutionary algorithms. Eng. Comput. 2016, 33, 580-602. [CrossRef]

147. Nilakantan, M.J.; Ponnambalam, S.G.; Huang, G.Q. Minimizing energy consumption in a U-shaped robotic assembly line. In Proceedings of the 2015 International Conference on Advanced Mechatronic Systems (ICAMechS), Beijing, China, 22-24 August 2015; pp. 119-124. [CrossRef]

148. Nilakantan, M.J.; Huang, G.Q.; Ponnambalam, S.G. An investigation on minimizing cycle time and total energy consumption in robotic assembly line systems. J. Clean. Prod. 2015, 90, 311-325. [CrossRef]

149. Sun, B.; Wang, L.; Peng, Z.P. Bound-guided hybrid estimation of distribution algorithm for energy-efficient robotic assembly line balancing. Comput. Ind. Eng. 2020, 146, 106604. [CrossRef]

150. Nilakantan, M.J.; Li, Z.; Tang, Q.; Nielsen, P. Multi-objective co-operative co-evolutionary algorithm for minimizing carbon footprint and maximizing line efficiency in robotic assembly line systems. J. Clean. Prod. 2017, 156, 124-136. [CrossRef]

151. Zhang, Z.; Tang, Q.; Li, Z.; Zhang, L. Modelling and optimisation of energy-efficient U-shaped robotic assembly line balancing problems. Int. J. Prod. Res. 2019, 57, 5520-5537. [CrossRef]

152. Zhang, Z.; Tang, Q.; Zhang, L. Mathematical model and grey wolf optimization for low-carbon and low-noise U-shaped robotic assembly line balancing problem. J. Clean. Prod. 2019, 215, 744-756. [CrossRef]

153. Zhang, B.; Xu, L. An improved flower pollination algorithm for solving a Type-II U-shaped assembly line balancing problem with energy consideration. Assem. Autom. 2020, 40, 847-856. [CrossRef]

154. Zhang, B.; Xu, L.; Zhang, J. A multi-objective cellular genetic algorithm for energy-oriented balancing and sequencing problem of mixed-model assembly line. J. Clean. Prod. 2020, 244, 118845. [CrossRef]

155. Zhang, B.; Xu, L.; Zhang, J. Developing mathematical model and optimization algorithm for designing energy efficient semiautomated assembly line. Comput. Ind. Eng. 2020, 149, 106768. [CrossRef]

156. Zhou, B.; Kang, X. A multiobjective hybrid imperialist competitive algorithm for multirobot cooperative assembly line balancing problems with energy awareness. Proc. Inst. Mech. Eng. Part C J. Mech. Eng. Sci. 2019, 233, 2991-3003. [CrossRef]

157. Li, Z.; Tang, Q.; Zhang, L.P. Minimizing energy consumption and cycle time in two-sided robotic assembly line systems using restarted simulated annealing algorithm. J. Clean. Prod. 2016, 135, 508-522. [CrossRef]

158. Frigerio, N.; Cornaggia, C.F.A.; Matta, A. An adaptive policy for on-line Energy-Efficient Control of machine tools under throughput constraint. J. Clean. Prod. 2021, 287, 125367. [CrossRef]

159. Chen, G.; Zhang, L.; Arinez, J.; Biller, S. Feedback control of machine startup for energy-efficient manufacturing in Bernoulli serial lines. In Proceedings of the 2011 IEEE International Conference on Automation Science and Engineering, Trieste, Italy, 24-27 August 2011; pp. 666-671. [CrossRef]

160. Su, H.; Frigerio, N.; Matta, A. Energy Saving Opportunities and Value of Information: A Trade-off in a Production Line. Procedia CIRP 2016, 48, 301-306. [CrossRef]

161. Jia, Z.; Zhang, L.; Arinez, J.; Xiao, G. Performance analysis for serial production lines with Bernoulli Machines and Real-time WIP-based Machine switch-on/off control. Int. J. Prod. Res. 2016, 54, 6285-6301. [CrossRef]

162. Jia, Z.; Zhang, L.; Arinez, J.; Xiao, G. Performance analysis of Bernoulli serial production lines with switch-on/off machine control. In Proceedings of the 2015 IEEE International Conference on Automation Science and Engineering (CASE), Gothenburg, Sweden, 24-28 August 2015; pp. 477-482. [CrossRef]

163. Fei, Z.; Li, S.; Chang, Q.; Wang, J.; Huang, Y. Fuzzy Petri Net Based Intelligent Machine Operation of Energy Efficient Manufacturing System. In Proceedings of the 2018 IEEE 14th International Conference on Automation Science and Engineering (CASE), Munich, Germany, 20-24 August 2018; pp. 1593-1598. [CrossRef]

164. Wang Junfeng Xue, J.; Duque, E.T.; Li, S.; Chang, Q. Fuzzy decision of machine switch on-off for energy efficient operation of manufacturing system. In Proceedings of the 2017 13th IEEE Conference on Automation Science and Engineering (CASE), Xi'an, China, 20-23 August 2017; pp. 1158-1162. [CrossRef]

165. Wang Junfeng Fei, Z.; Chang, Q.; Fu, Y.; Li, S. Energy-Saving Operation of Multistage Stochastic Manufacturing Systems Based on Fuzzy Logic. Int. J. Simul. Model. 2019, 18, 138-149. [CrossRef]

166. Wang, J.; Fei, Z.; Chang, Q.; Li, S.; Fu, Y. Multi-state decision of unreliable machines for energy-efficient production considering work-in-process inventory. Int. J. Adv. Manuf. Technol. 2019, 102, 1009-1021. [CrossRef]

167. Wang, J.; Fei, Z.; Chang, Q.; Li, S. Energy Saving Operation of Manufacturing System Based on Dynamic Adaptive Fuzzy Reasoning Petri Net. Energies 2019, 12, 2216. [CrossRef]

168. Mouzon, G.; Yildirim, M.B.; Twomey, J. Operational methods for minimization of energy consumption of manufacturing equipment. Int. J. Prod. Res. 2007, 45, 4247-4271. [CrossRef]

169. Frigerio, N.; Matta, A. Energy Efficient Control Strategy for Machine Tools with Stochastic Arrivals and Time Dependent Warm-up. Procedia CIRP 2014, 15, 56-61. [CrossRef]

170. Frigerio, N.; Matta, A. Energy-Efficient Control Strategies for Machine Tools With Stochastic Arrivals. IEEE Trans. Autom. Sci. Eng. 2015, 12, 50-61. [CrossRef] 
171. Marzano, L.; Frigerio, N.; Matta, A. Energy Efficient State Control of Machine Tools: A Time-Based Dynamic Control Policy. In Proceedings of the 2019 IEEE 15th International Conference on Automation Science and Engineering (CASE), Vancouver, BC, Canada, 22-26 August 2019; pp. 596-601. [CrossRef]

172. Squeo, M.; Frigerio, N.; Matta, A. Multiple Sleeping States for Energy Saving in CNC Machining Centers. Procedia CIRP 2019, 80, 144-149. [CrossRef]

173. Frigerio, N.; Matta, A. Analysis on Energy Efficient Switching of Machine Tool With Stochastic Arrivals and Buffer Information. IEEE Trans. Autom. Sci. Eng. 2016, 13, 238-246. [CrossRef]

174. Frigerio, N.; Matta, A. Analysis of an Energy Oriented Switching Control of Production Lines. Procedia CIRP 2015, $29,34-39$. [CrossRef]

175. Renna, P. Energy saving by switch-off policy in a pull-controlled production line. Sustain. Prod. Consum. 2018, 16, 25-32. [CrossRef]

176. Sun, Z.; Li, L. Opportunity Estimation for Real-Time Energy Control of Sustainable Manufacturing Systems. IEEE Trans. Autom. Sci. Eng. 2013, 10, 38-44. [CrossRef]

177. Duque, E.T.; Fei, Z.; Wang, J.; Li, S.; Li, Y.F. Energy Consumption Control of One Machine Manufacturing System with Stochastic Arrivals Based on Fuzzy Logic. In Proceedings of the 2018 IEEE International Conference on Industrial Engineering and Engineering Management (IEEM), Bangkok, Thailand, 16-19 December 2018; pp. 1503-1507. [CrossRef]

178. Fernandez, M.; Li, L.; Sun, Z. “Just-for-Peak” buffer inventory for peak electricity demand reduction of manufacturing systems. Int. J. Prod. Econ. 2013, 146, 178-184. [CrossRef]

179. Sun, Z.; Li, L.; Fernandez, M.; Wang, J. Inventory control for peak electricity demand reduction of manufacturing systems considering the tradeoff between production loss and energy savings. J. Clean. Prod. 2014, 82, 84-93. [CrossRef]

180. Hu, S.; Liu, F.; He, Y.; Hu, T. An on-line approach for energy efficiency monitoring of machine tools. J. Clean. Prod. 2012, 27, 133-140. [CrossRef]

181. Diaz, J.L.; Bermeo, M.; Diaz-Rozo, J.; Ocampo-Martinez, C. An optimization-based control strategy for energy efficiency of discrete manufacturing systems. ISA Trans. 2019, 93, 399-409. [CrossRef] [PubMed]

182. Chang, Q.; Xiao, G.; Biller, S.; Li, L. Energy Saving Opportunity Analysis of Automotive Serial Production Systems (March 2012). IEEE Trans. Autom. Sci. Eng. 2013, 10, 334-342. [CrossRef]

183. Brundage, M.P.; Chang, Q.; Li, Y.; Arinez, J.; Xiao, G. Implementing a Real-Time, Energy-Efficient Control Methodology to Maximize Manufacturing Profits. IEEE Trans. Syst. Man Cybern. Syst. 2016, 46, 855-866. [CrossRef]

184. Brundage, M.P.; Chang, Q.; Li, Y.; Arinez, J.; Xiao, G. Utilizing energy opportunity windows and energy profit bottlenecks to reduce energy consumption per part for a serial production line. In Proceedings of the2014 IEEE International Conference on Automation Science and Engineering (CASE), New Taipei, Taiwan, 18-22 August 2014; pp. 461-466. [CrossRef]

185. Zou, J.; Arinez, J.; Chang, Q.; Lei, Y. Opportunity Window for Energy Saving and Maintenance in Stochastic Production Systems. J. Manuf. Sci. Eng. 2016, 138, 121009. [CrossRef]

186. Li, Y.; Chang, Q.; Ni, J.; Brundage, M.P. Event-Based Supervisory Control for Energy Efficient Manufacturing Systems. IEEE Trans. Autom. Sci. Eng. 2018, 15, 92-103. [CrossRef]

187. Huang, Y.; Wang, J.; Li, S. Max-Plus Algebra Based Machine Sleep Decision for Energy Efficient Manufacturing. In Proceedings of the 2018 Chinese Automation Congress (CAC), Xi'an, China, 30 November-2 December 2018; pp. 3986-3991. [CrossRef]

188. Mashaei, M.; Lennartson, B. Energy Reduction in a Pallet-Constrained Flow Shop through On-Off Control of Idle Machines. IEEE Trans. Autom. Sci. Eng. 2013, 10, 45-56. [CrossRef]

189. Renna, P.; Materi, S. Switch off policies in job-shop manufacturing systems including workload evaluation. Int. J. Manag. Sci. Eng. Manag. 2021. [CrossRef]

190. Materi, S.; D'Angola, A.; Renna, P. A dynamic decision model for energy-efficient scheduling of manufacturing system with renewable energy supply. J. Clean. Prod. 2020, 270, 122028. [CrossRef]

191. Materi, S.; D'Angola, A.; Enescu, D.; Renna, P. Reducing energy costs and $\mathrm{CO}_{2}$ emissions by production system energy flexibility through the integration of renewable energy. Prod. Eng. 2021. [CrossRef]

192. Abikarram, J.B.; McConky, K. Real time machine coordination for instantaneous load smoothing and photovoltaic intermittency mitigation. J. Clean. Prod. 2017, 142, 1406-1416. [CrossRef]

193. Beier, J.; Neef, B.; Thiede, S.; Herrmann, C. Integrating on-site Renewable Electricity Generation into a Manufacturing System with Intermittent Battery Storage from Electric Vehicles. Procedia CIRP 2016, 48, 483-488. [CrossRef]

194. Beier, J.; Thiede, S.; Herrmann, C. Energy flexibility of manufacturing systems for variable renewable energy supply integration: Real-time control method and simulation. J. Clean. Prod. 2017, 141, 648-661. [CrossRef]

195. Schulze, C.; Blume, S.; Siemon, L.; Herrmann, C.; Thiede, S. Towards energy flexible and energy self-sufficient manufacturing systems. Procedia CIRP 2019, 81, 683-688. [CrossRef]

196. Schulz, J.; Scharmer, V.M.; Zaeh, M.F. Energy self-sufficient manufacturing systems-Integration of renewable and decentralized energy generation systems. Procedia Manuf. 2020, 43, 40-47. [CrossRef]

197. Popp, R.S.H.; Liebl, C.; Zaeh, M.F. Evaluation of the Energy Flexible Operation of Machine Tool Components. Procedia CIRP 2017, 63, 76-81. [CrossRef]

198. Biel, K.; Zhao, F.; Sutherland, J.W.; Glock, C.H. Flow shop scheduling with grid-integrated onsite wind power using stochastic MILP. Int. J. Prod. Res. 2018, 56, 2076-2098. [CrossRef] 
199. Santana-Viera, V.; Jimenez, J.; Jin, T.; Espiritu, J. Implementing factory demand response via onsite renewable energy: A design-of-experiment approach. Int. J. Prod. Res. 2015, 53, 7034-7048. [CrossRef]

200. Wang, X.; Ding, H.; Qiu, M.; Dong, J. A low-carbon production scheduling system considering renewable energy. In Proceedings of the 2011 IEEE International Conference on Service Operations Logistics and Informatics, Beijing, China, 10-12 July 2011; pp. 101-106. [CrossRef]

201. Liu, C.-H. Mathematical programming formulations for single-machine scheduling problems while considering renewable energy uncertainty. Int. J. Prod. Res. 2016, 54, 1122-1133. [CrossRef]

202. Liu, C.-H. Discrete lot-sizing and scheduling problems considering renewable energy and $\mathrm{CO}_{2}$ emissions. Prod. Eng. 2016, 10, 607-614. [CrossRef]

203. Fattahi, M.; Mosadegh, H.; Hasani, A. Sustainable planning in mining supply chains with renewable energy integration: A real-life case study. Resources Policy 2018, 101296. [CrossRef]

204. Zhai, Y.; Biel, K.; Zhao, F.; Sutherland, J.W. Dynamic scheduling of a flow shop with on-site wind generation for energy cost reduction under real time electricity pricing. CIRP Ann.-Manuf. Technol. 2017, 66, 41-44. [CrossRef]

205. Wang, S.; Mason, S.J.; Gangammanavar, H. Stochastic optimization for flow-shop scheduling with on-site renewable energy generation using a case in the United States. Comput. Ind. Eng. 2020, 149, 106812. [CrossRef]

206. Fazli Khalaf, A.; Wang, Y. Energy-cost-aware flow shop scheduling considering intermittent renewables, energy storage, and real-time electricity pricing. Int. J. Energy Res. 2018, 42, 3928-3942. [CrossRef]

207. Jin, T.; Subramanyam, V.K.; Castillo-Villar, K.K.; Sun, F. Optimal sizing of renewable microgrid for flow shop systems under island operations. Procedia Manuf. 2020, 51, 1779-1784. [CrossRef]

208. Subramanyam, V.; Jin, T.; Novoa, C. Sizing a renewable microgrid for flow shop manufacturing using climate analytics. J. Clean. Prod. 2020, 252, 119829. [CrossRef]

209. Wu, X.; Shen, X.; Cui, Q. Multi-Objective Flexible Flow Shop Scheduling Problem Considering Variable Processing Time due to Renewable Energy. Sustainability 2018, 10, 841. [CrossRef]

210. Zhang, H.; Cai, J.; Fang, K.; Zhao, F.; Sutherland, J.W. Operational optimization of a grid-connected factory with onsite photovoltaic and battery storage systems. Appl. Energy 2017, 205, 1538-1547. [CrossRef]

211. Nayak, A.; Lee, S.; Sutherland, J.W. Dynamic Load Scheduling for Energy Efficiency in a Job Shop with On-site Wind Mill for Energy Generation. Procedia CIRP 2019, 80, 197-202. [CrossRef]

212. Cui, W.; Li, L.; Lu, Z. Energy-efficient scheduling for sustainable manufacturing systems with renewable energy resources. Nav. Res. Logist. (NRL) 2019, 66, 154-173. [CrossRef] 